\title{
ARTICLES
}

\section{Anna Zalewska*}

\section{RELEVANT AND APPLIED ARCHAEOLOGY. THE MATERIAL REMAINS OF THE FIRST WORLD WAR: BETWEEN "FOUNDATIONAL" AND "BIOGRAPHICAL" MEMORY, BETWEEN "BLACK ARCHAEOLOGY” AND “CONFLICT ARCHAEOLOGY”}

\begin{abstract}
Zalewska A. 2013. Relevant and Applied Archaeology. The Material Remains of the First World War: between "Foundational" and "Biographical" Memory, between "Black Archaeology" and "Conflict Archaeology". Sprawozdania Archeologiczne 65, 9-49.

The principal object of deliberations in this article focuses on: 1. the status of archaeological reflection pertaining to the materiality of the recent past; 2 . the fates and roles of the material remains of World War I and their potential in shaping the temporal orientation; 3 . the opportunities and dangers stemming from the interest in the material remains of the recent past. The aim is to demonstrate: a) the close interdependence between archaeology's relevance and applicability; b) the dynamic character of the relation between archaeology, material remains and stakeholders; and c) the potential of archaeology to reinforce not only historical consciousness but also historical sensibility and the need for more attentive existence among things. As the significant challenges connected to the last aspects can be seen the dissemination with the help of archaeology the fact, that the number of soldiers of Polish descent that suffered across all WWI frontlines reached 1400 ooo of which approximately 500 ooo were killed! Theme for such thoughts' targeting is the willingness to draw attention to the uniqueness and importance of archaeology of the recent past.
\end{abstract}

Keywords: First World War Archaeology; memory; “floating gap"; foundational \& biographical archaeology; "black archaeology"; conflict archaeology.

Received: 11.03.2013; Revised: 28.06.2013; Accepted: 30.08.2013

* Institute of Archaeology, Maria Curie-Skłodowska University, Pl. M. Curie Skłodowskiej 5, 20-031 Lublin, azalew@op.pl 


\section{INTRODUCTION}

Among the most intriguing phenomena observed in archaeological thought is the reflectivity of the relation between the requirements of the spontaneous, undisciplined and somewhat unpredictable timeliness of social life and the research scope of the archaeological discipline. We always live in a certain "now", with a certain "before" and for a certain "after". According to the author of this assertion, the creator of the concept of recentivism Józef Bańka, it seems justified (and inevitable?) to direct the past towards current human existence. Recentivism (i.e. the philosophical doctrine advocating that whatever actually exists possesses a being that is only immediately present, and while any phenomenon can be described in any given tense, its potential truthfulness can only be expressed in relation to the present) seems to be helpful in establishing the philosophical framework for the archaeology of the recent past. It can also prove helpful in considering how far into the distant past we are able to travel, away from the present point of reference, to ensure that the benefits of this "step back" are still felt and that we are accompanied by a "strange sensation of actuality" (after Bańka 1986; 1991, 101-102). This stems from the fact that the expected benefit of the interest "devours" the temporal gap separating us from the event and fills the "black hole" between the archaeological past and the present (Rathje et al. 2001). Anything of interest in a given moment is indeed current, regardless of how distant is the past of the event as such. It is the very "interest" that causes an event from the past to lose its temporal horizon of remoteness. At the same time, the "expected benefit" shortens the perspective of our looking back into the past, which rationalises the actions and pursuits of people in the present.

This may be the reason why the archaeology of the recent past ("contemporary archaeology", "archaeology of us", archaeology of "super-modernity" etc.) is currently among the most important branches of the discipline, and an object of interest for a growing number of researchers and explorers of archaeological knowledge (Olivier 2001; Saunders 2002; González -Ruibal 2008). It is ever more common to see comprehensive and institutionalised realisation of the initial principles, somewhat divergent, but non-colliding goals of "archaeology of us": the drive towards deepening knowledge of material culture and adding detailed supplements to the (re)presentations of recent historical times, and the realisation of ethno-archaeological (González-Ruibal2007) and pedagogical values underlying the research (Shiffer et al. 1981; Buchli and Lucas 2001). From the perspective adopted herein the last goal is of particular interest, especially if we consider the ever stronger premise that not only is archaeology "in need of fixing", but also that such treatment is only feasible when more diverse voices are involved in the interpretation of the past.

This article has three sections. The first introduces the field of the archaeology of the recent past in general terms and is based on general humanistic premises (mainly archaeological, historical, cultural and mnemonological) and focuses on the fluidity of the disciplinary borders of archaeology and on its stability in pertaining to materiality. The core of 
the second section is a complex observation of the current after-effects (material and mental) of events during World War I in Eastern and Western Europe, particularly the initiation of chemical warfare during 1915 in the areas of Ypres (Belgium) and Bolimów (Poland). This leads to the conclusion that only under favourable conditions (social, political, historiographic) can material remains be causative and as such can be engaged in the public articulation of memory narratives. The third section of the article integrates two mutually exclusive, yet correlated, phenomena of illegal explorations (black archaeology) and socialized (applied archaeology) as key elements of the reflective relation between the strictly cognitive efforts of archaeologists and the pragmatism of social activity that accompanies them.

\section{ARCHAEOLOGY OF THE PRESENT AS THE SYNONYM OF ARCHAEOLOGY PER SE}

Rooting our thinking about archaeology in the present by no means condemns that which is distant. It is a way to expose two facts: that all residues constitute the reality of our present, and that the material traces of the recent past are fundamentally archaeological in the same way as the traces of the distant past (Olivier 2008; Holtorf and Piccini 2009; McAtackney et al. 2007). In practice however, most archaeologists will not even concern themselves with such matters because "modern remains" are, in a sense, rejected by definition as too recent i.e. non-archaeological - aptly observed Laurent Olivier in his deliberations on the recent past (une archeologie du passé proche) (Olivier 2008, 88-107). The problem of "omitting" begins when one is faced with the necessity to define the chronological boundary to separate what belongs to archaeology from that which does not. It is still not clear what criteria are to be employed in deciding whether, for example, simply "resorting to archaeological methods" can be treated as archaeology in the full sense of the word. At the same time, although there has been quite a long history of interest in material remains of the recent past, it is only recently that the necessary tools, methodology, and theoretical approaches have been combined to allow serious scientific contributions to the holistic study of it (Saunders 2007, 22-30; Scott and McFeaters 2011).

The boundaries of archaeology as a discipline remain obscure for a number of reasons. Projects gathered under the collective banner of archaeology of the recent past vary significantly in terms of both the objects of research and the scope of their problems or theoretical bases. Therefore, the relations of some studies described as "archaeological" with archaeological practice are in fact dubious at best as they are much closer in character to studies of material culture (after González-Ruibal 2008, 247). However, the primary reason for the blurred boundaries of archaeology and the still ambiguous status of the archaeology of the recent past seems to be the general unspoken reluctance to attempt their re-defining the scope of archaeology as such. Some explain it by the anxiety of both archaeologists and non-archaeologists caused by troubling the boundaries between the past and the present 
(Voss 2010, 181-182, 189) while others cite the aversion to the study of what we, or our relatives, have directly or indirectly experienced for both scientific and personal reasons (González-Ruibal 2007; Olivier 2008, 112-118).

There is also the frail basis of the force of habit in terms of the "existing" and "accepted" sample space. The gradual expansion of the scope of archaeology has resulted in perception of the issues related to nineteenth and twentieth centuries as archaeology per se. In a way, this is the result of research practices. Since the recommended standard has become a record of all archaeological data, the presence of residues of the modern and contemporary periods, repeatedly appearing in the structure of prehistoric archaeological sites, are documented and interpreted. This raises the importance of these findings from the "postdepositional distortions" to the informative entities which must be recorded (even if not fully appreciated).

At the same time, not without reason, more and more increasingly it is stressed (as aptly observed by González-Ruibal 2008, 252) that it is the archaeology of the contemporary past that has to do justice to the enormous relevance of things in our recent history. This means that it is worth paying more balanced attention to the collectives of humans and things that are involved in the historical processes that we study, taking into account the materiality of the world we live in, an issue that is achieving more and more importance in the social sciences (Latour 1993, 1996; Olsen 2006; Olsen et al. 2012, 12-14, Miller 2005). What mobilizes to this is the unique nature of things themselves (including the fact that "things resist our attempts to articulate them" and as such they are "irreducible to our representations of them", they are "more than things-for-us, they hold and guard an otherness", Olsen et al. 2012, 13-14; see also Miller 2005; Tilley et al. 2006). Over the last two decades there have been fundamental changes in the way that material culture has been studied and this has resulted in a widespread "new material sensibility" which manifests itself in the growing interest in even the most mundane things (Miller 2005; Saunders 2007, 231-251; Kowalski et al. 2008; González-Ruibal 2008, 252; Dunne 2012). These circumstances favour the acceptance of the thesis that negating the archaeological identity of the present or the recent past is nothing more than a point of view of aesthetic or historical character, one that is not grounded in the very nature of archaeological remains. According to Olivier $(2008,87)$ the present is an overture that opens up to the profusion of various pasts which precede contemporaneity and which are registered by it. In this way, archaeology of the present is indeed synonymous with archaeology as a whole, it is archaeology pers se.

\section{MATERIAL REMAINS OF THE FIRST WORLD WAR IN WESTERN AND EASTERN EUROPE}

Archaeology that is sensitive to the present is particularly useful in identifying the "cycles of material memory within which material evidence is modified, destroyed, buried, 
and eventually (once more) uncovered, so that it can continue as the "witness" of the past, one that can be either ignored or exhibited, disgraced or glorified" (Olivier 2001; 2008, 88; Dingli 2006; Ferguson et al. 2010; Buchli 2010). Admittedly, in the first instance, archaeology seems to be particularly helpful in providing material support for "foundational" memory (since it provides us with the fixed, material carriers of memory, such as memoria). But it should be also stressed that the "foundational" aspects of archaeology do not exhaust its function. As significant are also the manifestations of involving archaeology in "biographical memory" (which refers to the near present, to people, places and things that are close in time and space; it refers to personal experience and the frameworks that determine it). Those manifestations are the results of situations where archaeologists are appointed to act in very current contexts (e.g. research in Auschwitz, the graves of Katyń, exhumation of victims of the communist period 1948-1952) (types of memory distinguished after Assmann 2008; see also Kola 2005; González- Ruibal 2008, 249; Borić 2010; Kola and Sziling 2011).

I put here the argument that, since archaeological samples can highlight issues relating to the foundational and biographical memory, two modes / types of archaeology can also be distinguished (following Assmann's steps). Firstly, foundational archaeology (which would reach far into the past and is marked by the mythology of the nation's, state's and community's origins; the myth functions on the basis of persistently objectified carriers etc., memoria - and is shaped and complemented artefactually through permanent carriers (whose acquisition and activation is the responsibility of a select group of advocates (?) and it is a trait characteristic of cultural memory). Secondly there is biographical archaeology, which would be closer to the present and referring to personal history, that of one's loved ones, places and things. This refers to personal experience and the frameworks that determine it. The key to the distinction between the two types of archaeology postulated here lies in observing the ways in which material relics related to past events operate in the present, and what are the roles and functions of importance they are assigned too. The decisive factor here is not (always) time (both in Flanders and Mazovia one hundred years has passed since the original deposition of finds which are / could be today considered as archaeological). So, if it is not the distance in time that causes something to become archaeology, what is it? What makes something become an object of intentional and planned actions? While asking that question one should carefully analyze different contexts in which archaeology becomes relevant, and reasons which explain why "something" becomes the subject of intentional and planned activities, and why are (only) some material correlates of the recent past incorporated into memory and/or history? Is, in this matter, any generalization possible?

Observations on the phenomenon of time orientation may be helpful here. These are based on the fact that people within societies naturally tend to focus their interests of the past and its tales on chronologically the most recent and most distant times, while the "in-between" is often passed over and as such not very well known. Jan Assmann, following 
J. Vansina's assumptions, attributes the trait of universality to the fact that both records of the past - the two ends without a middle - correspond to two memory frames that differ from each other in certain fundamental areas, as they refer to "cultural memory" or "communicative memory" (see Vansina 1985, 24-26; Assman 2008, 66-67, 71). At the same time, he observes that a gap emerges within collective memory as a consequence of its bimodal function, i.e. between the mode of "foundational memory" which relates to origins and requires effort and often professional care for its persistently objectified carriers; and the mode of "biographical memory", which is a matter of natural growth in which anyone can freely participate. The "biographical memory is therefore treated as the "communicative memory" and it delimits the scope of "now". Naturally, this division occurs only in analytical terms, since in the everyday life of a given community of memory the two modes of memory are never distinguished. Consequently, from the point of view of community members, the "floating gap" cannot be perceived as static. It does not exist as stable because the planes of reference to the past at both ends are fluid and follow each other in a direct sequence (Niethammer 1995, 26). But, should the "unrepresented past", "empty periods", or "time outside of interest" be omitted by archaeologists? These observations bring us to the second major issue of this article.

Drawing on a comparative analysis of several aspects illustrating the current condition of the First World War's battlefields (i.e. their present existence, the ways in which they are used today, their reception and symbolic features) I attempt to identify the elements that so far have had a significant influence on their perception, social status, and function of material depositories of memory about the events of a century ago. I coined the term Gasscape to relate to the discussed phenomenon when approaching the question of what stance $2 \mathrm{O}^{\text {th }}$ century archaeology can and should take on terrorscapes, and consequently how it should cope with the context of post-gas sites as palimpsests with long time-lines (1915-2015). Gasscapes encourage us to consider how the relations between the modern world and World War I are manifested, and view them in a way not limited to the prism of legacy, i.e. things already constituted in their functions as receipts, tender sheets in a planning projects (e.g. the fates of sites (places) where remains of World War I trenches are uncovered during evaluations in advance of road construction), museum collections, heirlooms, souvenirs, stimulants of senses and sensitivities, etc.

In the Western European case of a former Gasscape, the present-day landscape around Ypres is flourishing as a 'Pride of the Nations', as the city's brand and as a significant tourist and heritage product. By contrast, the potential of (material) memory of the Gasscape on the Eastern Front is almost completely ignored (Pajewski 2004, 227, 281-286; Sergio 2011). Both places witnessed the initiation of the use of chemical weapons by the German side in 1915. In Flanders (April 22) and in Mazovia (May 31) the front was at a stalemate and soldiers experienced the war of attrition and the violation of the Conventions through the use of poisonous gasses and tear gas (Martinez 1996; Lepick 1998; Cook 2002; Buffetaut 2008; Brüger 1930, 86 za: Kaliński 2010, 109-110). Despite the fact that the clash in 1914- 
1915 at the Rawka and Bzura Rivers in Poland can be called "the Battle of Ypres of eastern front" (Kaliński 2010, 3, 181), there are almost no material and mental traces left by those events on the eastern Gasscape, especially when compared to Ypres. A critical evaluation of the condition of the material remains of the First World War allows us to conclude that: (1) while in Belgium they have a real impact on memory communities and communities of interpretation, while (2) in Poland, the efficacy of after-war remains is very small. Reflection on the functioning of the material remains suggests that they may reflect a "disturbance" in the experience of the passage of time, but even more interesting the remains may (to some extent) guide the way in which the time, history and contemoraneity is experienced. The presence of the remains of World Wars I and II in contemporary Poland (their actual number and character deserve a more thorough investigation), as well as their various coincidences with archaeological research, is fairly common, which is hardly surprising given the recent history of our country. However, the attitude towards such "interpretative static" is generally rather conservative. This confronts us with questions about the degree of archaeological participation in Poland in completing the history of the Great War and the cognitive and social consequences of its involvement in the issues.

In the epistemological sense, even in Polish archaeology the "sample space" can be defined as more than four million years (Hensel 1973, 23, 171; Tabaczyński 1987; Cyngot and Zalewska 2012, 193-5). Although for some archaeologists it is still not obvious that our discipline, for permanent and serious reasons, closely interlocks with the problems of the recent past and with the discourse of memory (Olsen, 2010, 107-128; Moshenska 2010; Borić 2010, Zalewska 2012a). In research practice manifestations of expanding the boundaries of archaeology should be considered as relevant and justifiable. This is due to the currently accepted norms and rules (methodological and methodical), including guidelines for archaeological surveys which must be undertaken in advance of building and infrastructure projects. As a result, more and more archaeological reports provide those interested in the archaeology of the recent past (also in the events of a hundred years ago) with interesting reading. By way of example, I will limit myself here to comments on the content of archaeological reports from the area of hostilities on the Rawka and Bzura.

In 2008, under a permit issued on 2nd June by the Conservator of Monuments for Mazowsze Province (Decision no 639/2008), excavations were conducted as part of preinvestment works on the A2 motorway. Apart from 17 anthropogenic objects recovered (dating to the Neolithic, Bronze Age, and Roman period) there were also "objects related to the construction of defensive structures during World War I". Meticulous archaeological analyses and functional characteristics of the objects were undertaken. For instance objects were interpreted as: "communication", "shooting" and "fire" trenches or "dugouts". For example: feature 19 ("a line of pine stakes ( 5 to $7 \mathrm{~cm}$ in diameter) embedded in the object's floor along with corresponding holes and a pine log of about 5 meters") and feature 21 ("layers held organic remains including pine needles and bark which were interpreted as water proofing of a fire trench") - were described by archaeologists as 
particularly interesting. The researchers also observed "the lack of characteristic features typical of defensive installations of this type (rifle shells, military gear, everyday objects, garbage, etc.)". "The dirt-filled objects held only three unused, disassembled rifle rounds and several lead, shrapnel balls" (the emphasised text after Wyczółkowski and Cyngot 2008 - my thanks to authors for making the report available to me in advance of publication). In relation to this document, it is important to mention the fact that the archaeological report made reference to the following: (a) the context (historical and social) of the events relating to the deployment of chemical weaponry in the area; (b) the circumstances of a visit to the field by Fritz Haber, the originator of military gas deployment; (c) the estimated death toll among soldiers gassed during the first successful use of chloride as a chemical warfare agent, which took place at Ypres and Bolimów in 1915; (d) the places where soldiers were buried (for example so-called "brotherly graves", i.e. mass graves in Wiskitki, Miedniewice and Guzów); and (e) the terrible consequences of the frontline activity on the local population (many people were killed, all buildings were levelled along with telegraph posts, railway tracks and industrial plants). The report also mentions that during the interwar period wartime cemeteries were well maintained (e.g. three cemeteries in Humin, Joachimów-Mogiły and Złota were established) which can be commented as revealing a certain sensitivity of the authors of the report to the issues of the attitude towards the past in the past. It was only after World War II that most of the cemeteries fell into decay, a situation that pertained until the 1980 s when several finally received some maintenance care (in Bielice, Ruszki and Bolimowska Wieś) (Wyczółkowski and Cyngot 2008). These issues may be considered an unusual (although from the perspective advocated in this article very valuable, promising and suggestive) element of an archaeological report. Issues described by archaeologists in that report can be seen as valuable elements of the archaeological report, as the results of discerning research and as proof of the sensitivity of the researchers to the problems of material remains of the recent past.

However, archaeological reports are not always sufficient, as can be illustrated by the grossly inaccurate information contained in The results of rescue archaeological research conducted in Wiskitki community (vide Ziemska 2010, 46-7). I will limit myself here to the analysis of only the first sentence of section 3.1.3. of that report which states: "After the capture of Sochaczew by the XXV German Corps on 23 December 1914 clashes took place on the left bank of Bzura, from Eowicz tothe mouth of the river" (Ziemska 2010, 46). However, firstly, Sochaczew was not conquered until the end of the action at Rawka; secondly, the XXV German Corps never captured Sochaczew (see Martinez 1996, 26; Haber 2002, 30; Kaliński 2010, 9-12). This example of historical ignorance by archaeo-logists is harmful and requires deeper diagnosis.

While both reports above can be considered (for very different reasons) to be exceptional, the Results of archaeological studies conducted in Bolimów between 2005 and 2007 at site 9, Skierniewice, Lodz voivodship (Świątkiewicz 2005-2006) provide a fairly representative account of the current state and condition of World War I archaeology in 
Poland. In this case a multi-phase site (discovered in 1983: AZP 60-58/9) was also examined during pre-investment work. Many remains, ranging from the Bronze Age through to the sixteenth and nineteenth centuries and the World Wars were found there. The report noted that during 1914/1915, and in 1944 this area was a battlefield, after which the remains (earth and wood-earth) of the fortifications remained at the field. These were described as "untypical" objects for archaeological research, "the exploration of which was connected with a certain risk for workers and could be conducted only in strict cooperation with the supervision of an engineer". But particularly important in the context of this article is a key line of the report: "Until now, twentieth century field fortifications have not been an object of interest for archaeologists, even though, in every aspect, they are equal to other works of military architecture, and, generally speaking, they are archaeological sites too. This requires a deeper methodological reflection" (Świątkiewicz 2005-2006, 203204). There is therefore a need to establish a comprehensive methodology adequate especially in situations where the present is mixed with prehistory as a palimpsest (Bailey 2007, 203-208; Olivier 2008, 193 ff; Lucas 2010, 350 ff).

The recent past entangled with the present, is nothing but an archaeological sequence, which naturally adds to everything that preceded it, through processes that also take away, in a material and mental sense. Long duration (longue durée) reflects on all archaeological sites taken here into account. They are palimpsestic in a double sense: stratigraphic and metaphoric (as anthropological entities). Layering settlement processes and post-depositional effects is the clue of cognitive challenge for archaeologist.

The British archaeologist Nicholas J. Saunders, an advocate of the complex, increasingly sophisticated interdisciplinary concept of "conflict archaeology" (which is not restricted to battlefields, nor to large scale wars between nations, but embraces any kind of conflict, at any level, and in which the constantly shifting multidimensional aftermaths of conflict are as important as the conflict as well), presents the compelling case that perhaps no other kind of archaeology is so deeply and poignantly anthropological as Great War archaeology, and the archaeology of twentieth century conflict more widely (Saunders 2004, 30-31; 2007). That is why this approach can be seen to assist in transformation of our knowledge (and I might add also, our sensibility and sense of historicity) in conjunction with our understanding of the world and other conflicts as well as ourselves (also in relation to things). N. Saunders also stresses the enduring and ambiguous relationship between war and archaeology - they both create in the very act of destroying. The author seems to suggest that archaeology and some of the aftermaths of war "share the power of creating": Thus, conflict may live on as histories and propaganda by shaping attitudes, behaviours and material culture towards war even in times of peace, manifested "not only in the physical remains of destruction, but also in new and rejuvenated monuments and landscapes of commemoration, new museological engagements with conflict, the agendas of the media in representing war, new ideas of war heritage and burgeoning multi-million dollar commerce in tourism places associated with conflict”. A crucial fact for Saunders is 
also that apart from economic motives, there may be a philosophical, perhaps almost spiritual, justification in returning the war-torn surface to agriculture (AZ: and for the memory of contemporary societies when they have been forgotten, as in Poland), but there can be surely no excuse for purposefully digging deep without powerful and convincing intellectual and ethical agendas, or legal requirements to do so. Excavating battle zone conflict sites should not be treated as the entertainment, and "should not be treasure hunting dressed up as archaeology" (Saunders 2012, ix, xiv).

I propose here to treat the suggestions and experiences of Western colleagues involved in the "archaeology of conflict" as a help to develop an antidote to the "black archaeology" in the "bloodlands" (T. Snyder's term describing the Eastern and Central-Eastern areas of Europe). Archaeology, especially "mature Great War archaeology" has the potential to transform our knowledge (and I will also add, our sensibility and historicity) and understanding of twentieth century wars and ourselves. As such it can be seen as the handy training ground for relevant and applied archaeology. It should be also stressed, that conflict archaeology is not limited to research on battlefields, but refers to all aspects of the conflict including its multi-dimensional and constantly changing consequences, and what seems to be no less remarkable, everything that preceded the conflict, and what followed after it, and is perpetuated in the physical archive of the ground.

\section{„MILITARIA”: BETWEEN “BLACK ARCHAEOLOGY” AND "APPLIED ARCHAEOLOGY"}

As time passed, bodies sank deeper, and interest in wartime memorabilia quickened! - remarked the leading researcher on the development of an anthropological and modern scientific archaeology of the First World War in one of his pivotal texts (Saunders 2002, 101). The progressive intensification of looting at the places where remnants of twentieth century warfare can still be found is a pan-European problem. Fortunately, at least in Belgium, the interest in militaria is not exhausted by "black archaeology". Numerous initiatives combining fully professionally cognitive tasks and marketing, maintenance and managerial (CRM), academic and non-academic (e.g. The European Group for Great War Archaeology. No Man's Land, founded in 2003) are crucial for the field of interacting with war memorabilia. It is no exaggeration to say, however, that Belgian archaeology is struggling with the problem of the "black archaeology" (which contains also the remains of the Great War) - similarly to Polish archaeology.

The "black archaeology" phenomenon of illegal excavations, often linked to trafficking finds, is growing. It is estimated that in Poland there are about 100 ooo detectorists (Trzciński 2010), while five years ago the number was around 35 ooo. There was almost no problem of looting of cultural material in the communist period (although according to experts in this field, this problem also existed at the time, but has not yet been established). 
The period 1993-1994 is identified as a turning point for "black archaeology" in Poland (Cultural Heritage Cooperation 2005, 29 - 32). The problem of so-called "detectorists", "treasure hunters", "looters", is not considered amongst the general public as significant or substantial (see Saunders 2007, 9-17; Trzciński 2010; Ulst 2010). This hinders effective prevention of trafficked objects. To this problem can be added: (a) imperfect legislative solutions, (b) pragmatic reasons, which are in conflict with the ethical and/or economic objectives of the protection of the archaeological heritage, (c) 'non-obviousness' (cognitive, ethical, aesthetic) of the conditions and consequences of the treatment of the material remains of conflicts from twentieth century (d) the reluctance of archaeologists, conservators and regional curators to take responsibility for twentieth century material heritage, etc. As one of the obstacles can be also perceived (e) the relative passivity of community of archaeologists and lack of clear rules in cooperation between professional archaeologists and "volunteer archaeologists" or "amateur archaeologists" (those who want to preserve the heritage and are driven by noble motives). This results in both a serious tension between archaeologists, with a deepening discredit of their social position and a powerlessness in the teaching of preventive measures. As many important observations on the matter has been already made (see Brodie et al. 2000; Bursche 2001a-b; Szpanowski 1999, 2001a, b; Trzciński 2010) I will limit myself here to define illegal archaeology, and then to sketch its relationship with First World War archaeology.

"Black archaeology" as defined by I. Ulst $(2010,154)$ means "all the single or groupbased activities which are related to the illegal non-scientific excavation, removal and selling of archaeological heritage originating from illicit or official excavations, including but not limited to the preliminary research and communication activities, search and excavation works, removal and cleansing of finds, any support activities, networking and contracting, and the offering for sale and selling of finds to the previously identified or non-identified buyers in the country of origin and abroad". Although I fully accept this complex definition of "black archaeology" as applicable in Poland, it requires expansion to include the longterm consequences (moral, epistemological, ethical) of such actions.

The task is a difficult one, particularly when its observation is accompanied by the awareness that, as in Poland, officials responsible for prosecuting and penalising these sorts of crimes are often themselves advocates of this hobby. I base this opinion on the conclusions of those who have had dealings with prosecutors, border guardsmen, police officers and soldiers (including retirees) often present among the "explorers", which is naturally not without significant consequences. They lobby for each other (also people from outside their own professional circles) and present the opinion that it is simply a form of harmless entertainment (a way to deal with the stress of everyday life). I am unable to name specific persons and without sufficient evidence they will go largely unpunished. To counter the phenomenon and to propose an antidote that will initiate the process of resocialization of the participants of "black archaeology" in this unfortunate business, further in-depth study is required with the aim of determining the motivation, circumstances 
and consequences of the actions of particular individuals belonging to the highly varied group of “ detectorists", "enthusiasts”, robbers, plunderers and looters. Unfortunately the scope of such research lies far beyond the competences of an archaeologist. However, since the phenomenon in question is yet to receive proper sociological or cultural attention in our country, one may assume that (unless the situation changes) archaeological circles may indeed be forced, regardless of considerable obstacles, to attempt to face the challenge independently (naturally with the support of competent individuals). The results and consequences of such research will take us a step closer towards relevant and applied archaeology.

It is useful, in illustrating the theoretical assumptions of relevant and applied archaeology, to consider a grassroots initiative of uncovering, retrieving and exhibiting World War I relics in the Bolimów area (Łódzkie Province). On August 2012, in the forest by the river Rawka, around the fragile material remains of a mine crater, the planned, official and noninvasive stage of exploration of a site with material remains from World War I began. It was the result of a bottom up initiative. The target was to define the scope of archaeological works to be conducted on site in September and October on the initiative of the Friends of Bolimów Region Society („Stowarzyszenia Inicjatywa Ziemi Bolimowskiej”) and on behalf of the planned Museum of Military and Applied Technology in Bolimów. The preliminary exploration was conducted with the help of the initiators and members of Exploration and History Society group "Łódź”, supervised by an archaeologist from the University of Łódź (Piotr Nowakowski, PhD). The researchers hoped to uncover trenches destroyed by an explosion where, according to German regimental documents, a number of soldiers in battle gear were buried. The investigation uncovered several small items connected with the battle fought a century ago, including the transport caps from Lishin Grenades. These can be interpreted as confirming information from the regimental records of the hand grenades widely used by the Russians in that area (vide German Regimental Unit History of 227 Reserve Infantry Regiment, here after Kaliński 2010). Researchers hoped to recreate certain events and the reality of war skirmish which were not (unlike most German successes which are usually described in detail in regimental annals) recorded by German officers.

However the explorations have not proved successful, despite (a) significant involvement of people, (b) the fact that the crater would benefit from conservation care (it is treated both as a garbage dump by local gardeners and as a space for exploration by illegal looters), and (c) the merits of undertaking scientific surveys (i.e. the very limited data on the gas attack on the Eastern Front and the actions preceding it may be a result of intentional seizing, or at least marginalizing of the "episode" by the Germans). The potential for deepening our historical awareness by recognizing the material aftermaths of the combatants' activities in the daily routine of warfare was lost. This was a local event, nowhere outside the scope of interest of a local newspaper. But what is also intriguing in that case, in common with many bottom up initiatives connected to battlefields survey, the amateur 
participants of the project solicited archaeological participation and supervision. As the negative side of such 'cooperation' I perceive the fact that it was not driven by the amateurs' recognition of the essential / substantive support from professional archaeologists, but by their fear that they would be punished for illegal use of detectors or by their needs for legal status of activity (for example due to the specific ownership constraining easy access to the field of interest and/or due to the planned continuation of public commemoration or tourist development). Such an attitude is reasonable for a few reasons. Certainly, 'they' would be punished (due to strict legislative rules in Poland) and, additionally their activity needs to be 'patronised' / formalized / professionalized (due to the social rules in our country). But also, which is the saddest, they do not expect research support, because they see the shortage of professionals dedicated and specialized in twentieth century archaeology. It seems from the analyzed cases, that the archaeologists and the people, formerly known as audience have switched positions. It can be diagnosed as symptomatic and as, to some extent, an affront to the authority of archaeologists and, what is much more important, as a diminished opportunity to common protection of material remains of twentieth century conflict.

It is not my intention to argue that everyone should be allowed to freely go out and dig. I fully stand by the opinion expressed in the "Declaration of Polish Archaeological Circles on the Problem of Detectorists" of 14 May 2012. Here, Archaeologists expressed a "deep concern about the devastation of a growing number of archaeological sites by amateur and illegal digs conducted by persons using electronic metal detecting equipment and about the initiatives aimed at changing the current law on the protection and preservation of historical sites". The document reads:

"Archaeological heritage is a delicate, fragile, non-renewable and finite cultural resource. It constitutes the property of the whole society in whose name it is managed and protected, for the common good, by designated conservation services supported by trained archaeologists and scientific, conservational and museum institutions charged with ensuring common access to said archaeological heritage and the values it represents. Therefore, all movable archaeological relics ought to remain the property of the State" (Art. 1, after www. snap.org.pl).

Particularly interesting is the assertion in this passage of common public interest in relation to the material remains of the Great War. In our country material remains of World War I do not play significant roles in shaping historical awareness because (in general terms) they are neither elements of "foundational" nor of "biographical" memory. They are parts of a "floating gap." But they are not anyone's. Thus they are present, but their status is doubtful, which is not conducive to their longer-term survival.

Meanwhile, in Belgium, formal recognition as "archaeological objects" was not attributed to the material remains and relics of World War I until the start of the twenty-first century. The legislative Act, accompanied by amendments, introduced to the national law saw a radical change in the attitudes of those who had, until that time, seen it as their personal 
duty and honour to care for and protect these monuments. Before then, between 1992 and 2003, there were several semi-formal groups of amateur 'battlefield archaeologists' that thrived in part because there was then little official archaeological involvement in First World War heritage. It was in a sense, a "free market", where, "once the landowner's permission was obtained, digging could take place almost everywhere, constrained only by manpower, enthusiasm, finances and the weather" (Saunders 2007, 12-13).

Interestingly, the vicissitudes of the so-called Diggers (amateur archaeologists who began digging in 1992 and soon focused their attention on an area which had not been developed since the end of the First World War, and was the site of the first German gas attack in 1915!) and their significant contribution to the preservation of the battlefields in Flanders were noticed and appreciated by archaeologists who have continued their work in the last decade and invited them to participate. This step allowed a seamless continuation of the effort of remembrance. Indeed, the decision is hardly surprising given that the Diggers' knowledge, experience and familiarity has since allowed a number of important and valuable finds to be made (Smith 1999). The value and feedback of such cooperation can clearly be seen in both state-run and private local museums. However, despite the fact that some individuals were not looters and their digging had a serious purpose, they did not replace the opportunistic battlefield scavengers who searched for bodies and artefacts in far less scrupulous and ethical manner. These scavengers are "desecrating their own ancestors' remains". They also destroy inherently pan-European archaeological heritage (Saunders 2007, 11-12).

The growing problem of illegal searches by detectorists, the destruction caused by local investments and the need to complete the work on the construction of the A-19 motorway through the Ypres Salient battlefields (especially Pilckem Ridge, which was witnessed dramatic losses during the Third Battle of Ypres at Passchendaele, in July-August 1917) motivated Belgians to create the first ever department dedicated to First World War Archaeology. The IAP (Belgium's Institute for Archaeological Heritage) gave the highest priority to creating such institution. : "This was a bold step for a new and as yet un-theorised kind of archaeology confronted with formidable methodological challenges". The aims and objectives of the department established in 2003 were as follows: (a) undertaking archaeological research, inventories, maintenance of the historical relics and site management - all integrated aspects of the region's First World War heritage; (b) responsibility for directing, monitoring, and co-ordinating the many private activities and initiatives undertaken by museums, amateur excavators, historians, and other interested parties; (c) creating a repository of specialised knowledge on such varied topics as trench and dugout construction, military maps, uniforms and equipment, armaments, munitions, and memorabilia etc. (Dewilde et al. 2004).

All these goals are grounded in the attitude of accepting archaeology not just as a scientific discipline dedicated to the discovery of the remains of the past and their description, explanation, interpretation or evaluation, but also as a socio-cultural activity, which pro- 
vides arguments, meanings and motives for the current cultural communication. This type of activity involving archaeologists matches the view of Richard Rorty, that "cognition is not so much a matter of proper understanding of reality, but rather of developing habits to cope with it" (Rorty 1999, 9, 56). In her comments on Rorty's proposition, Ewa Domańska encourages the development of research tools and interpretative categories whose efficiency may be measured not by the adequateness of their depiction, explanation or representation of the subject matter, but rather by the effectiveness with which they bring about change, establishing potential and preparing "bearing" for the future (Domańska 2012, 77). Such a "bearing" for future archaeology can be applied archaeology, by which I mean an archaeology that reacts to external (extra-academic, also extra-cognitive) stimuli by adapting its practice accordingly. Its key elements are the archaeologists' accountability for the level of historical awareness and sensitivity among various social groups (which facilitate not just an ethical change but also influence the subject matter by, for example, expanding the frameworks to include archaeology of the recent past). What is important in applied archaeology is its positive approach to grassroots research initiatives and appreciation of the activities of amateurs/volunteers to whom archaeologists offer professional support.

If we assume that applied archaeology is also the relevant archaeology - as the one which satisfies all the assumptions and expectations (methodical and methodological) considered to be optimal at the time and place for the community of professional archaeologists, by the members of the community (society), such archaeology will be referring to the application of archaeological research and its results to address contemporary human problems, including (but not limited to) issues that involve cultural resource management, heritage tourism and development, long-term modelling of human/environment dynamics, and public education aimed at awareness and stewardship of archaeological remains. Its main objective is to ensure compatibility with current social needs, since all archaeology is in the public interest and must respond to issues of public concern (see Downum and Price 1999, 227; Gillespie 2008). Such an approach can find support in the experience of "applied history" (Kelly 1978; Traba 2009, 2012), "applied anthropology", "civic initiatives" or as proposed recently by E. Domańska "rescue history". The relevant and applied Archaeology, as it departs from an "authoritarian model" (focused only on scientific and pragmatic ratio of authorities including archaeologists) to a "social model" (taking into consideration common social ratio and engaging community members in archaeological activities - see relevant comments on that topic by Czerniak 2011), can be treated as a remedy to the side effects of the so-called "democratisation of archaeology". It results among other things, from the availability of equipment (e.g. detectors, geo-radars) and from vastly improved information flow (e.g. 'instructional' videos from illegal digs posted on the internet). It is high time for archaeologists to react with preventive, educational efforts, including actions to oppose "black archaeology".

In Poland a very large and expanding group of people from "black archaeology" assume, reasonably enough, that they are the only one interested in discovering, collecting 
and interpreting the material remains of the recent past (especially military remains, including traces of the Great War). Until archaeologists change their attitude towards the remains of the recent past detectorists will continue to confirm themselves in their belief that they are doing "missionary work” („we save from complete decay what is left” from crucial events of the twentieth century) with innocence of action („,we do not carry away anything to anyone, we are just looking for what no one but us wants to see"). Passivity (mainly of archaeologists) and a focus on their own perceptions of what is right (mainly of detectorists - however those positions can be easily switched as I have illustrated above) is fraught with irreversible consequences.

\section{CONCLUSIONS. RELEVANCE AND APPLICABILITY OF ARCHAEOLOGY}

The diagnosis of the problems sketched above leads me to assume that the findings of the First World War, their social representations and the ways in which contacts with them are experienced are, or may be, of particular interest to those focused on the archaeology of the recent past (including "conflict archaeology"), as well as for those interested in socialized versions of archaeology (applied archaeology, community archaeology, public archaeology). Systematic study of Great War archaeology, which is already a formal and institutionalized domain in Western Europe, provides relevant and inspirational insights for better understanding the relationship: archaeology - memory - society, and the functions that material traces of the past (may) play. The references to the events of a hundred years ago and to their physical correlates, confront us with critical and fluid boundaries (shaped among others by archaeologists) between "living memory” (,biographical”), and "foundational memory". The material relics and our relationship with them is a good starting point to reflect on the essence of current, applied and relevant archaeology.

The current form of Great War archaeology provides a particularly interesting field for reflection. While in the West, especially in Belgium and France, we can speak about the pro-active role of archaeologists in widening the "sample space", in Poland the role seems to be reactive. I assume that the pro-activity results from cognitive curiosity and stimulates the passage of the goals and interests of the different communities, and re-activity is the result of compulsive and forced responses to social needs and to circumstances (such as construction projects that require archaeological research).

I would venture to say, even though it may sound seditious, that the insightful diagnosis of the problems outlined in this article indicates that in creating the character of relations between archaeologists and the general public and in expanding archaeology's field of interest, an important role is played by "detectorists". With regard to the relics from World War I such influence is fully reflected in Belgium. But, also in Poland signs of it can be observed. For example, the aforementioned Declaration of 14 May 2012 states, inter 
alia: "Archaeology is not a science whose interests and research capacities are limited to only a certain period of the past. Archaeological methods have been successfully applied to locations and objects from a relatively near past, such as WWI and WWII battlefields, martyrdom sites or abandoned industrial facilities. In all such cases archaeological studies yielded valuable information which could not have been obtained with other methods" (art. 7, za: www.snap.org.pl). In practice, however, that (although forced by depressing circumstances) the progressive and clearly articulated position of archaeologists is (too) often undermined by officials who decide what is worthy of protection. Also, the indirectly and directly articulated reluctance of archaeologists towards the material remains of the recent past results in these types of remains falling into nothingness, or into the "black market space”. Unfortunately, so far I cannot specify the percentage of twentieth century military and other finds associated with recent past, but their significant numbers (and their meaning) cannot be ignored by archaeologists.

The attitude of accepting the perception of archaeology as the rudiment of improved historical sensitivity and awareness and lively memory encourages the acceptance of tangible remains of the recent past as vital subjects for reading the palimpsest. This means that the recipients begin to realise the complexity of its message, they engage in premeditated enquiry into that which is not immediately apparent and assume anteriority, thus acknowledging the dynamics/variability of meanings attributed to a given vehicle of information, e.g. a remnant of the past. This can contribute to a better understanding of the tension between the past - present and future, between memory and forgetting, between texts and textures of what is left to us from the past. Archaeology of second degree (and archaeology of reactivated matter - I have proposed and sketched those concepts in different places, for details see a.o. cf. Zalewska 2009; 2012) can be seen as supportive of these efforts. It tends to pay attention to all forms of secondary exploitation of archaeological knowledge and material traces of the past, including those dark, immoral and moot.

I do not venture here to question the fact that it remains the responsibility of archaeologists to ensure proper retrieval of traces of the past and their incorporation into the existing network of associations, meanings and goals. However, various social, cultural and market related changes have resulted in a situation where the responsibility no longer belongs solely to them. We can observe a growing tendency to treat archaeological knowledge as an object of "palimpsestic reading" (after Zygmunt Bauman), which means that its recipients begin to realise the complexity of its message. Undoubtedly, key importance in this context must be attributed to the circumstances under which archaeologists create the vision of the past while at the same time transforming the present into another present.

In fact, I feel I should take the argument even further and claim that it is the decision of archaeologists to withhold, for whatever reasons, their involvement in the modern and highly technological world, that invites the actions of people illegally plundering the material remains of the war. 
Following the lead of previous observations and thoughts, I attempt to establish theoretical bases for a hybrid of applied-relevant archaeology (in Polish: archeologia stosow(a)na), which would fit with the cognitive and ethical standards of archaeology while at the same time remaining sensitive to social needs. Listening attentively to those needs is not an easy task and, due to the prevalent tendencies to trivialise, commercialise or downright destroy archaeological heritage, can be overwhelmingly frustrating. It is, however, impossible to neglect or ignore the intentions and actions of stakeholders (including regionalists or enthusiasts of 2oth century wartime history, militarists, and looters), particularly given their often significant impact on:

(a) the real extension of archaeology's sample space;

(b) the shaping of the temporal orientation and memory of communities and individuals alike;

(c) the issues of memory continuity, of memory of what is past, but still within us;

(d) the attitude towards the dead (including their earthly remains which are of interest to both archaeologists and grave robbers);

(e) the social order (including respect for ownership); and

(f) the attitude towards rules and laws established with the preservation of the heritage for future generations in mind.

It is this very perspective that reveals the urgent need for an interdisciplinary debate on what should be treated as archaeological monuments of 2oth century conflicts, and why, as well as on what action can most effectively ensure the due care and respect for such monuments. Interestingly, pursuant to Art. 6.3 of the Act of 23 July 2003, one of the available forms of protecting a historical monument, namely listing it in the Registry of Historical Monuments, barely (with the exception of wartime burials) applies to this category. According to the Act, protection and conservation should apply to archaeological monuments, regardless of their condition, including in particular traces of prehistoric and historic settlements, burial grounds, burial mounds, and relics of commercial, religious and artistic activity. Traces of military struggles are not mentioned. The reasons for this are many and require urgent, in-depth analysis.

Archaeological sites are not alone in their duration, and the trajectory of their transformation from past to present is affected by a wide variety of factors and causative agents over the centuries. The preliminarily sketched arguments seem to support the opinion that, at the current stage, perceiving archaeology as the rudiment of improved historical sensitivity / sensibility and awareness in the context of gasscapes requires truly superhuman optimism. Luckily, humans are not the only ones capable of teaching lessons in history. It is also the domain of inanimate matter, including matter activated by the first deployment of chemical weaponry a hundred years ago. Fragmentary and distorted though it may be, it still remains non-absent. 


\section{References}

Assmann J. 2008. Pamięć kulturowa. Pismo, zapamiętywanie i tożsamość polityczna $w$ cywilizacjach starożytnych. Warszawa.

Bańka J. 1986. Ontologia bytu aktualnego. Katowice 1986.

Bańka J. 1991. Traktat o czasie. Czas a poczucie dziejowości istnienia w koncepcjach recentywizmu i prezentyzmu. Katowice.

Bailey G. 2007. Time perspectives, palimpsests and the archaeology of time. Journal of Anthropological Archaeology 26, 198-223.

Borić D. (ed.) 2010. Archaeology and Memory. Oxford.

Brodie N., Doole J. and Watson P. 200o. Stealing History: the Illicit Trade in Cultural Material, Cambridge.

Buchli V. 2010. Memory, Melancholy and Materiality. In D. Borić (ed.), Archaeology and Memory. Oxford, 204-210.

Buchli V. and Lucas G. (eds). 2001. Archaeologies of the contemporary past. London - New York.

Brüger O. 1930. Geschichte des Infanterie - Regiments v.d. Marwitz (8. Pomm). Weltkriege 19141918. Nr 61. Berlin.

Bursche A. 2001. Archeolodzy i poszukiwacze - przyczyny konfliktu cz. 1. Odkrywca 4 (28), 37-40.

Bursche A. 2001. Archeolodzy i poszukiwacze - przyczyny konfliktu cz. 2. Odkrywca 5 (29), 39-42.

Buffetaut Y. 2008. Ypres April 22nd 1915. The first Gas Attack.

Cook Tim. 2002-2003. "Dying Like so Many Rats in a Trap". Gas warfare and the Great War soldier. The Army Doctrine and Training Bulletin 5(4), 47- 56.

Cultural Heritage Cooperation in the Baltic Sea States: Report 4 - 2005. The Monitoring Group on Cultural Heritage, the Council of the Baltic Sea States (available at: balticheritage.net/reports/report4.pdf

Cyngot D. and Zalewska A. Zmienność i dynamiczność podziałów tematycznych w archeologii. In

S. Tabaczyński, D. Cyngot, A. Marciniak and A. Zalewska (eds.), Przeszłość społeczna. Próba konceptualizacji. Poznań, 193-206.

Czerniak L. 2011. Dla kogo są wykopaliska. Profesjonaliści i społeczeństwo. In A. Marciniak, D. Minta Tworzowska and M. Pawleta (eds.), Wspótczesne oblicza przesztości. Poznań, 177-186.

Dewilde M., Pype P., de Meyer M., Demeyere F., Lammens W., Degryse J., Wyffels F. and Saunders N. J. 2004. Belgium's new department of First World War archaeology. Antiquity 78(301), http://www.antiquity.ac.uk/projgall/saunders/ (access 3.03.2013).

Domańska E. 2012. Historia egzystencjalna. Krytyczne studium narratywistyki i humanistyki zaangażowanej. Warszawa.

Downum Ch. E. and Price L. J. 1999. Applied Archaeology. Human Organization 58, 226-239.

Dunne J. 2012. 'Dead Man's Penny': a biography of the First World War bronze memorial plaque. In N. S. Saunders (ed.), Beyond the Dead Horizon. Studies in Modern Conflict Archaeology. Oxford, 1-13. 
Dingli S. M. 2006. Responsibility towards the heritage of mankind. In Ch. Scarre and G. Scarre (eds), The Ethics of Archaeology: Philosophical Perspectives on Archaeological Practice. Cambridge, 219-241.

Ferguson R., Harrison R. and Rose D. 2010. Heritage and the recent and contemporary past. In T. Benton (ed.), Understanding heritage and memory. Manchester, 277-315.

Gillespie S. D. 2008. Teaching Archaeology as Anthropology. Archaeology Papers of the American Anthropological Association 13(1), 87- 97.

González-Ruibal A. 2007. Making things public: archaeologies of the Spanish Civil War. Public Archaeology 6, 203-26.

González-Ruibal A. 2008. Time to Destroy. An Archaeology of Supermodernity. Current Anthropology 49(2), 247-279.

Haber L. F. 2002. The poisonous cloud. Chemical Warfare in the First World War. New York.

Hensel W. 1973. Archeologia żywa. Warszawa.

Holtorf C. and Piccini A. (eds.), 2009. Contemporary archaeologies: Excavating now. Frankfurt am Main.

Kaliński S. 2010. Ataki gazowe w bitwie pozycyjnej 9 Armii Niemieckiej nad Rawkq i Bzurq 19141915. Przemyśl.

Kelly R. 1978. Public history. Its Origins, Nature and Prospects. The Public Historian 1(1), 16-28.

Kobyliński Z. and Szpanowski P. 2009. Metal detector users and archaeology in Poland: the current state of affairs. In S. Thomas and P. Stone (eds.), Metal Detecting and Archaeology. Woodbridge, 13-24.

Kokowski A. 2011. Archeologia naprawdę żywa. In M. Ausz, G. Miliszkiewicz, H. Stachyra and D. Szewczuk (eds.), Muzea skansenowskie we wspótczesnej edukacji historycznej. Lublin, 13-24.

Kola A. 2005. Archeologia Zbrodni. Oficerowie polscy na cmentarzu ofiar NKWD $w$ Charkowie. Toruń.

Kola A. and Sziling J. (eds.) 2011. Charków-Katyń-Twer-Bykownia. W 7o. Rocznicę zbrodni katyńskiej. Zbiór studiów. Toruń.

Kowalski J., Piasek W., and Śliwa M. (eds) 2008. Rzeczy i ludzie. Humanistyka wobec materialności. Olsztyn.

Latour B. 2010. Splatając na nowo to, co spoteczne. Wprowadzenie do teorii aktora-sieci. Kraków.

Lepick O. 1998. La grande guerre chimique 1914-1918. Paris.

Lucas G. 2010. Time and the archaeological archive. Rethinking History 14 (3), 343-359.

Martinez D. 1996. Der Gaskrieg 1914-1918. Bonn.

McAtackney L., Palus M. and Piccini A. (eds.) 2007. Contemporary and historical archaeology in theory. Papers from the 2003 and 2004 CHAT Conferences (= Studies in Contemporary and Historical Archaeology 4; British Archaeological reports. International Series 1677). Oxford.

Miller D. 1994. Artefacts and meanings of things. In T. Ingold (ed.), Companion Encyclopedia of anthropology. London, 396-419.

Moshenska G. 2010. Working with Memory in the Archaeology of Modern Conflict. Cambridge Archaeological Journal 20, 33-48. 
Niethammer L. 1995. Po tej stronie „dryfującej luki” (floating gap). Pamięć zbiorowa i konstrukcja tożsamości w dyskursie naukowym. In K. Plat and D. Mihran (eds.), Generation und Gedächtnis. Erinnerungen und kollektive Identitäten. Opladen, 25-50.

Olivier L. 2001. The archaeology of the contemporary past. In V. Buchli and G. Lucas (eds.), Archaeologies of the contemporary past. London and New York, 175-88.

Olivier L. 2008. Le sombre abime du temps: memoire et archeologie. Paris.

Olsen B. 2010. In Defence of Things: Archaeology and the Onthology of Objects. Lanham.

Olsen B., Shanks M., Webmoor T. and Witmore T. 2012. Archaeology. The Discipline of Things. Berkeley, Los Angels, London.

Pajewski J. 2004. Pierwsza Wojna Światowa 1914-1918. Warszawa.

Pawleta M. 2011. "The Past industry": selected aspects of the commercialization of the past and products of archaeological knowledge in contemporary Poland. Sprawozdania Archeologiczne 63, 9-54.

Rathje W. L., LaMotta V. and Longacre W. A. 2004. Into the black hole: Archaeology 2001 and beyond... In B. Cunliffe, W. Davies, I. Hodder, C. Renfrew and A. Snodgrass (eds.), Archaeology: The Widening Debate. Oxford, 497-539.

Rorty R. 1999. Obiektywność, relatywizm i prawda (= Pisma filozoficzne 1). Warszawa.

Saunders N. J. 2001. Matter and Memory in the Landscapes of Conflict: The Western Front 19141999. In B. Bender and M. Winter (eds.), Contested Landscapes: Movement, Exile and Place. Oxford, 38-40.

Saunders N. J. 2002. Excavating Memories: archaeology and the Great War. Antiquity 76, 101-108.

Saunders N. J. 2004. Material culture and conflict: the Great War, 1914-2003. In N. J. Saunders (ed.), Matters of Conflict: Material Culture, Memory and the First World War. London, 5-25.

Saunders N. J. 2007. Killing Time. Archaeology and First World War. Stroud.

Saunders N. J. 2012. Introduction: Engaging the Materialities of Twentieth and Twenty-first Century Conflict. In. N. J. Saunders (ed.), Beyond the Dead Horizon. Studies in Modern Conflict Archaeology. Oxford and Oakville, x-xiv.

Schiffer M. and Gould R. (eds.) 1981. Modern Material Culture. The Archaeology of Us. London.

Scott D. D. and McFeaters A. P. 2011. The Archaeology of Historic Battlefields: A History and Theoretical Development in Conflict Archaeology. Journal Archaeol Res 19, 103-132.

Sergio A. 2011. Bolimów 1915. Polskie Verdun. Polska Zbrojna 26-27, 44-49.

Shanks M., Platt D. and Rathje W. L. 2004. The perfume of garbage. Modernity/Modernism 11(1), 68-83.

Smith T. 1999. Of Ypres Battlefields - Disappearances and Discovery. Western Front Association Bulletin 53, 58-59.

Świątkiewicz P. 2008. Wyniki badań archeologicznych przeprowadzonych w sezonach 2005-2007 w Bolimowie na stanowisku 9, pow. skierniewicki, woj. łódzkie. In S. Kadrow (ed.), Raport 2005-2006. Warszawa, 189-205.

Szpanowski P. 1999. „Detektoryści” - miłośnicy przeszłości czy rabusie starożytności? Prawdziwe oblicze „poszukiwacz skarbów” w Polsce. $Z$ otchłani wieków 2. Warszawa, 72-75. 
Szpanowski P. 2001a. Archeolodzy i poszukiwacze Cd. Odkrywca 7 (31), 52-53.

Szpanowski P. 2001b. Eksploratorzy chcą chronić zabytki (?). Z otchłani wieków 4, 103-112.

Tabaczyński S. 1987. Archeologia sìredniowieczna: problemy, zìródła, metody, cele badawcze. Warszawa.

Traba R. 2012. Pożyteczność uczenia się historii. Historia stosowana: między "History sells" a "Public History”. In E. Domańska, R. Stołbiecki and T. Wiślicz (eds.), Historia - dziś. Teoretyczne problemy wiedzy historycznej. Poznań (in print).

Traba R. 2009. Historia stosowana. Pamięć i krajobraz jako nośniki badań i edukacji historycznej. In R. Traba, Przeszłość a teraźniejszość. Polskie spory o historię na początku XXI wieku. Poznań, $135-148$.

Trzciński M. 2010. Przestępczość przeciwko zabytkom archeologicznym. Problematyka prawnokryminalna. Warszawa.

Ulst I. 2010. The problems of "black archaeology" in Estonia. Estonian Journal of Archaeology 14(2), 153-169.

Vansina J. 1985. Oral Tradition as History. Madison.

Voss L. B. 2010. Matter Out of Time: The Paradox of the "Contemporary Past". Archaeologies: Journal of the World Archaeological Congress 6 (1), 181-92.

Wyczółkowski D. and Cyngot D. 2008. Wyniki badań wykopaliskowych, wyprzedzających budowe autostrady A-2, na obszarze stanowiska archeologicznego Miedniewice 3, nr AZP 6o-59/49 oraz $w$ jego strefie ochronnej. Warszawa (unpublished elaboration of rescue excavations stored in the Archive of Institute of Archaeology and Ethnology, Polish Academy of Sciences).

Zalewska A. 2003. (review) Victor Buchli and Gavin Lucas (eds.), Archaeologies of Contemporary Past. Archeologia Polski 48, 252-275.

Zalewska A. 2012. Archeologia studiowaniem teraźniejszej przeszłości. In S. Tabaczyński, D. Cyngot, A. Marciniak and A. Zalewska (eds.), Przeszłość spoteczna. Próba konceptualizacji. Poznań, 1097-1121.

Zalewska A. 2012a. Archeologia (uspołeczniona) w polu pamięci, tradycji i wiedzy. In J. Adamowski and M. Wójcicka (eds.), Pamięć jako kategoria rzeczywistości (= Tradycja dla wspótczesności. Ciągłość i zmiana 6). Lublin, 75-94.

Zalewska A. In print. Roadside lessons of historical sensibility and awareness. The roles and the meanings of the material points of references to The Great War. The historicity of eastern and western European Gasscapes.

Ziemska U. (ed.) 2010. Wyniki archeologicznych badań ratowniczych przeprowadzonych na stanowisku VIII w Nowej Wsi gm. Wiskitki, woj. Mazowieckie. Program - Autostrada A-2. Warszawa. 


\section{Anna Zalewska}

\section{ARCHEOLOGIA STOSOW(A)NA. MATERIALNE POZOSTAŁOŚCI PIERWSZEJ WOJNY ŚWIATOWEJ: MIĘDZY PAMIĘCIA „FUNDACYJNĄ” A „BIBLIOGRAFICZNÄ,, MIĘDZY „CZARNA ARCHEOLOGIĄ” A „ARCHEOLOGIĄ KONFLIKTU”}

\section{WPROWADZENIE}

Jednym z intrygujących zjawisk w przestrzeni dziejów myśli archeologicznej jest zwrotność relacji między potrzebami spontanicznej, niezdyscyplinowanej i poniekąd nieprzewidywalnej aktualności życia społecznego, a zakresem badań dyscypliny archeologicznej. Żyjemy zawsze w jakimś „teraz”, ale z jakimś „przed” i dla jakiegoś „potem”. W świetle opinii autora tej konstatacji, twórcy koncepcji recentywistycznej Józefa Bańki nieuniknione wydaje się ukierunkowywanie przeszłości na aktualny byt człowieka. Recentywizm (tj. doktryna filozoficzna wyrażająca pogląd, iż to co istnieje dla nas, ma byt wyłącznie aktualny oraz, że opis jakiegoś zjawiska jest możliwy we wszystkich czasach, ale jego potencjalna prawdziwość może się wyrażać jedynie poprzez teraźniejszość) pomocny jest w refleksji nad tym, w jak odległą przeszłość winniśmy się cofać z aktualnego punktu widzenia, by pożytek z tego „kroku wstecz” był jeszcze dla nas widoczny i by towarzyszyło nam „dziwne wrażenie aktualności” (Bańka 1986; 1991, 101-102). Wrażenie to powoduje, że zdarzenia z przeszłości tracą czasowy horyzont oddalenia i że zapełniana jest „czarna dziura” pomiędzy przeszłością archeologiczną, a teraźniejszością (Rathje et al. 2004). Aktualnym będzie to wszystko, co w danym momencie zwraca naszą uwagę i budzi zainteresowanie, chociażby odnosiło się do odległej przeszłości. Jednocześnie, ów sygnalizowany powyżej „pożytek” skraca perspektywę wybiegania w przeszłość. Między innymi tym tłumaczyć można powody dla których archeologia bliskiej przeszłości staje się aktualnie jednym z kluczowych odłamów dyscypliny i stanowi obiekt zainteresowań coraz liczniejszej grupy badaczy i odbiorców wiedzy archeologicznej (Olivier 2001; Saunders 2002; González-Ruibal, 2008).

W sposób coraz bardziej kompleksowy realizowane są naczelne cele archeologii współczesności: dążenie do pogłębienia wiedzy na temat kultury materialnej współczesnego świata oraz realizacja etno-archeologicznych (González-Ruibal2007) i pedagogicznych wartości badań (Shiffer et al. 1981; Buchli, Lucas 2001). Nie oznacza to bynajmniej umniejszania znaczenia naukowego/poznawczego elementu dociekań archeologicznych. Chodzi mi raczej o to, by poprzez uwypuklenie zwrotności związku pomiędzy badaniami archeologicznymi i społeczeństwem unaocznić m.in. powody dla których przeszłość, teraźniejszość i przyszłość powinny być rozumiane jako współ-konstytutywne, zaś ślady, teksty, znaki, znale- 
ziska archeologiczne i miejsca jako sprawcze. Zakładam, że okaże się to pomocne w zmaganiach z zanikającą materialnością przeszłości i z popadaniem często bardzo istotnych wydarzeń (jak np. udział Polaków w działaniach zbrojnych na froncie wschodnim I Wojny Światowej) w tryby zapomnienia.

Artykuł składa się z trzech części: w pierwszej z nich, w terminach ogólnych (głównie historiograficznych, kulturoznawczych, pamięcioznawczych) została przedstawiona refleksja nad płynnością granic dyscyplinarnych archeologii i nad stabilnością jej związku z materialnością świata. Zasadnicza dla drugiej części jest kompleksowa obserwacja procesu przemian i aktualnych następstw (materialnych i mentalnych) pierwszo-wojennych działań z okolic Ypres (w Belgii) i Bolimowa (w Polsce). Trzecia część artykułu odnosi się do (1) nielegalnej działalności osób zainteresowanych pozostałościami Wielkiej Wojny („czarna archeologia”) i do (2) działań środowisk archeologicznych, które wychodzą naprzeciw potrzebom społecznym i w reakcji na nie oraz z ich uwzględnieniem tworzą programy badawcze, angażując w nie osoby spoza środowiska archeologicznego (,archeologia stosowana”). Zjawiska te, omówione w ścisłym związku z konkretnymi przejawami przenikania przeszłości sprzed stu lat do teraźniejszości, traktuję jako istotne w procesie określania cech zwrotnej relacji między stricte poznawczą działalnością archeologów, a praktyką i pragmatyką działań społecznych, które im towarzyszą.

\section{ARCHAEOLOGIA TERAŹNIEJSZOŚCI JAKO SYNONIM ARCHEOLOGII SAMEJ W SOBIE}

Wyjście w myśleniu o archeologii od teraźniejszości (oraz od uczynienia kluczową, kwestii aktualności wszelkich pozostałości materialnych po przeszłości), bynajmniej nie skazuje tego, co odległe na pominięcie. Jest to sposób na wyeksponowanie dwóch faktów: że wszystkie pozostałości tworzą rzeczywistość naszej teraźniejszości oraz, że materialne ślady bliskiej przeszłości są fundamentalnie archeologiczne w tym samym stopniu, co ślady z odleglejszej przeszłości (Olivier 2008; Holtorf, Piccini 2009; McAtackney et al. 2007). W praktyce jednak, większość archeologów nie zawraca sobie głowy sprawami bliskiej przeszłości, ponieważ „pozostałości nowoczesne są w pewnym sensie z definicji odrzucane jako niedawne tzn. nie archeologiczne" - jak to celnie diagnozuje Laurent Olivier w swych rozważaniach na temat bliskiej przeszłości (une archeologie du passé proche) (Olivier 2008, 88-107). Problem „pomijania” ujawnia się wraz z potrzebą wytyczenia granicy chronologicznej pomiędzy tym, co wynika z archeologii i tym co już nią nie jest. Wciąż nie są oczywiste kryteria rozstrzygania tego, czy na przykład "zastosowanie metod archeologicznych" może być traktowane jako archeologia. Jednocześnie, dopiero ostatnio kształtowane są narzędzia, metodologie i teoretyczne podejścia, pozwalające na poważne i holistyczne studia nad materialnością bliskiej przeszłości (Saunders 2007, 22-30; Scott, McFeaters 2011). 
Granice dyscypliny archeologicznej pozostają niejasne z wielu powodów. Projekty zbierane pod wspólnym szyldem archeologii współczesności znacząco różnią się między sobą, a niektóre z nich mają dość wątpliwy związek z faktyczną praktyką archeologiczną (González-Ruibal 2008, 247). Poczuciu „mętności granic” archeologii sprzyja też aprioryczna niechęć archeologów do redefiniowania zakresu przestrzeni poznawczej. Niektórzy tłumaczą ją lękiem przed kłopotami, które mogą wyniknąć z zakłócenia granicy między przeszłością i teraźniejszością (Voss 2010, 181-182, 189), inni, awersją (wynikającą zarówno z powodów poznawczych jak i osobistych) do studiowania tego, czego my i nasi bliscy bezpośrednio doświadczaliśmy (González-Ruibal 2007; Olivier 2008, 112-118).

Równie istotna wydaje się „siła” przyzwyczajenia do „zastanej” i „uzgodnionej” przestrzeni prób. Stopniowe poszerzanie zakresu chronologicznego w kierunku okresów niedawnych doprowadziło do tego, że problemy odnoszące się do XIX i XX w. coraz częściej są postrzegane jako archeologia per se. Poniekąd, jest to wynik praktyk badawczych. Od czasu, gdy zalecanym standardem stało się rejestrowanie wszelkich danych archeologicznych, również obecność pozostałości z okresów nowożytnych i współczesnych, notorycznie pojawiających się w strukturze pradziejowych stanowisk archeologicznych, jest dokumentowana i coraz częściej interpretowana wieloaspektowo. Podniosło to rangę tych znalezisk. Jednocześnie, nie bez przyczyny, coraz częściej zwraca się ostatnio uwagę na to że, to archeologia bliskiej przeszłości musi oddać sprawiedliwość ogromnemu znaczeniu rzeczy w naszej bliskiej historii i „symetrycznym” tj. wzajemnie się uzupełniającym i współtworzącym powiązaniom między rzeczami i ludźmi (Latour 2010; Olsen 2010; González Ruibal 2008, 252). Mobilizuje do tego przede wszystkim sama wyjątkowość rzeczy (m.in. fakt, że wymykają się one naszym reprezentacjom, że sq czymś więcej niż tylko rzeczami - dla nas, za: Olsen et al. 2012, 13-14; por. też Miller 2005; Tilley et al. 2006).

Obserwowalne jest rosnące zainteresowanie fenomenem materialności (Miller 1994). W ciągu ostatnich dwóch dekad, doszło do zasadniczych przemian w sposobie studiowania kultury materialnej. W efekcie narodziło się, w kontekście szeroko doświadczanego „zwrotu ku materialności” swoiste „uwrażliwienie na materię” (określenie za: Shanks, Platt, and Rathje 2004), któremu ulegają liczni badacze, również spoza kręgów archeologicznych (Miller 2005; Saunders 2007, 231-251; Kowalski et al. 2008; González-Ruibal 2008, 252; Dunne 2012). Okoliczności te sprzyjają akceptacji tezy, że negowanie tożsamości archeologicznej teraźniejszości jest jedynie punktem widzenia - estetycznym lub historycznym, dla którego nie da się znaleźć oparcia w samej naturze pozostałości archeologicznych. Według L. Oliviera (2008, 87) „teraźniejszość to jedynie uwertura, która się otwiera na całą obfitość przeszłości, które poprzedzały aktualność i które są w niej zarejestrowane”. Archeologia teraźniejszości jest w rzeczywistości całą archeologią. Jest archeologią pers se. 


\section{MATERIALNE POZOSTAŁOŚCI WIELKIEJ WOJNY WE WSCHODNIEJ I ZACHODNIEJ EUROPIE. MIĘDZY ZAPOMNIENIEM A „ARCHEOLOGIA KONFLIKTU"}

Archeologia wyczulona na teraźniejszość, jest szczególnie pomocna w identyfikowaniu „cykli pamięci materialnej” w czasie których, świadectwa materialne mogą być modyfikowane, niszczone, grabione i ewentualnie (ponownie) odkrywane, po to by mogły trwać jako „świadkowie” - zarówno pomijani, jak i eksponowani, hańbieni i gloryfikowani, interpretowani lub ignorowani (Olivier 2001; 2008, 88; Dingli 2006; Ferguson et al. 2010; Buchli 2010). Wprawdzie, w pierwszym odruchu, archeologia wydaje się szczególnie pomocna w dostarczaniu materialnych punktów oparcia dla pamięci „fundacyjnej” (np. trwałych zobiektywizowanych nośników tzw. memoriów), ale należy notorycznie podkreślać, że zadania archeologii nie wyczerpują się w tej (zwłaszcza standardowo rozumianej) przestrzeni. Za istotne uznać należy przejawy angażowania archeologii w pole „pamięci biograficznej” (tj. odnoszącej się do bliskiej teraźniejszości, do bliskich ludzi, miejsc, rzeczy, do własnych doświadczeń i determinujących je warunków ramowych). Stanowią one wyniki sytuacji, w których archeolodzy są powoływani do działań w bardzo aktualnych kontekstach, począwszy od badań w Auschwitz, poprzez mogiły katyńskie, a skończywszy na pracach archeologiczno- ekshumacyjnych ofiar władz komunistycznych 1948-1952, (rozróżnienie typów pamięci za Assmann 2008; zob. też Kola 2005; González-Ruibal 2008, 249; Borić 2010; Kola, Sziling 2011).

Stawiam tu tezę, że skoro w przestrzeni prób archeologii wyróżnione być mogą zagadnienia odnoszące się do „pamięci fundacyjnej” i do „pamięci biograficznej”, to wyróżnione być mogą również dwa tryby / typy archeologii tj. archeologia fundacyjna (która odnosiłaby się do prapoczątków, w tym do pradziejów i która wymagałaby zabiegów i profesjonalnej troski o trwale zobiektywizowane nośniki) i archeologia biograficzna (której przedmiot badań wyznaczałby zakres “teraz” i ustanawiany byłby, w naturalny sposób, jako efekt bieżącej codzienności). Kluczowe dla rozróżnienia postulowanych tu dwóch typów archeologii, zdaje się być to, jakie funkcje, role i znaczenia przypisywane są w teraźniejszości materialnym reliktom i korelatom wydarzeń z przeszłości. Przy czym, co ciekawe: nie (zawsze) jest tu decydujący czynnik czasu. Można to zobrazować radykalnie odmiennymi losami i znaczeniami materialnych pozostałości po zachodnim i po wschodnim froncie Wielkiej Wojny. W obydwu wypadkach, upłynęło sto lat od chwili pierwotnej depozycji tego, co dziś uznawane jest/lub może być za znaleziska archeologiczne związane z tym konfliktem. Jeżeli zatem, to nie odległość w czasie powoduje, że coś się staje archeologią, to warto zapytać co powoduje, że „coś” staje się przedmiotem intencjonalnych i planowych działań (odgrywając role w przestrzeni pamięci „fundacyjnej”)? Co sprawia, że (tylko) niektóre korelaty wydarzeń z bliskiej przeszłości stają się elementami pamięci lub/ i historii? Czy możliwe są $\mathrm{w}$ tej materii jakiekolwiek sądy nomograficzne? 
Pomocne wydają się tu uwagi na temat fenomenu orientacji temporalnej, polegającego na tym, że społeczeństwa w naturalny sposób koncentrują swoje zainteresowania przeszłością i opowieści o niej, na czasach najbliższych i najdawniejszych chronologicznie podczas, gdy przestrzeń „pomiędzy” bywa zazwyczaj pomijana i jako taka mało znana. Jan Assmann, odnosząc się do obserwacji Jana Vansina, przypisał cechę uniwersalności temu, że oba rejestry pamięci - końce bez środka, odpowiadają dwóm zazębiajacym się jej ramom, które istotnie się od siebie różnią odnosząc się do pamięci kulturowej i pamięci komunikatywnej (por. Vansina 1985, 24-26; Assman 2008, 66-67, 71). Jednocześnie, zauważył on, że luka wytwarza się w pamięci zbiorowej na skutek bimodalnego jej funkcjonowania, tj. między modusem pamięci „fundacyjnej” a modusem pamięci „biograficznej”. Oczywiście, podział ten obowiązuje wyłącznie analitycznie. Teoretycznie, luka tworzy się pomiędzy pamięcią komunikatywną a kulturową, w płynnym odniesieniu do wydarzeń z przeszłości tj. to, co było ważkim elementem przeszłości dla naszych przodków, nie jest nim dla nas. Czy jednak, to, co aktualnie nie podlega re-prezentacji, co popada w trudno definiowalny rozłam, między „wspólnotą przeżyć” ludzi żyjących w danym okresie, a „symboliką kulturową przyszłych pokoleń" (por. Niethammer 1995, 26) powinno umykać uwadze i trosce archeologii?

Ten dylemat prowadzi wprost do drugiego kluczowego w tym artykule zagadnienia. Jest nim próba określenia potencjału pozostałości po Wielkiej Wojnie i ich aktualnych losów, ról i znaczeń. Dokonałam tego, poprzez wstępne porównanie dwóch konkretnych krajobrazów pogazowych ( $w$ analizie uwzględnione zostały materialne ślady in situ, ekspozycje muzealne i inne formy re-prezentacji związane z krajobrazem (po)gazowym (który określam jako Gasscape) odnoszącym się do użycia broni chemicznej w czasie Pierwszej Wojny Światowej, a zwłaszcza do ataków gazowych z 1915 roku.

Termin Gasscape, zastosowałam po raz pierwszy (na Konferencji EAA, Helsinki 2012) dla opisania fenomenu materialnych pozostałości po atakach gazowych, jakie miały miejsce w trakcie pierwszej wojny światowej, na frontach wschodnim i zachodnim, w odniesieniu do pytania o to, jak archeologia może i powinna ustosunkowywać się do krajobrazów związanych z doświadczaniem traumy („traumascapes”) czy terroru („terroscapes”), a tym samym, jak powinna radzić (sobie) w kontekście pogazowego krajobrazu z uwzględnieniem jego palimpsestowej natury i długiego trwania (1915- 2015). Gasscape skłania do myślenia o przejawach relacji współczesnego świata z I wojną, również inaczej niż wyłącznie przez pryzmat tego, co zastane, tj. poprzez rzeczy już usytuowane w swoich funkcjach np. dowodów historycznych, muzealiów, pamiątek, upominków etc. Materialne pozostałości pierwszej wojny to również potencjalnie sprawcze społecznie stymulatory zmysłów i wrażliwości, czy „karty przetargowe” w projektach planistycznych, głównie w kontekście budowy autostrad i tras szybkiego ruchu. Np. obecność licznych materialnych reliktów Wojny Totalnej wpłynęła na charakter i zakres prac przed-inwestycyjnych, poprzedzających budowę autostrady A-19 w Belgii tam, gdzie odkryte zostały relikty działań zbrojnych sprzed prawie 100 lat, natomiast nie miały żadnego wpływu na działania inwestycyjne w rejonie Rawki i Bzury, gdzie zbudowano autostradę A-2. 
Porównanie dwóch Gasscapes odnosi się do odmiennych kontekstów: zachodniego, gdzie materialne punkty odniesienia do Wielkiej Wojny są wręcz hołubione i skutecznie eksponowane jako nośniki pamięci (do niedawna „biograficznej”, a w ostatnim czasie głównie „fundacyjnej”) oraz wschodniego, gdzie są one niemal całkowicie zapomniane, bądź stają się przedmiotem indywidualnych pragnień (głównie kolekcjonerskich) i żądz (głównie zysku). Wyjściowo (tj. w roku 1915) krajobrazy te oraz materialne korelaty związane z ówczesnymi działaniami frontowymi, miały poniekąd analogiczny charakter. Dziś są one radykalnie różnie traktowane (Pajewski 2004, 227, 281-286; Sergio 2011). Zachodni krajobraz pogazowy to flandryjski krajobraz wokół miasta Ypres. Wschodni, to mazowiecki krajobraz nad Rawką i Bzurą (wokół miasteczka Bolimów). W obydwu tych miejscach doszło do zainicjowania użycia broni chemicznej przez stronę niemiecką w 1915 roku. Zarówno tam we Flandrii (22 kwietnia 1915 roku), jak i tu na Mazowszu (31 maja 1915 roku), nie mogący wywalczyć znaczącej przewagi żołnierze doświadczali pełni dramatu pierwszej wysoce ztechnologizowanej wojny pozycyjnej oraz pogwałcenia II deklaracji haskiej z roku 1899 o zakazie używania pocisków gazowych (Martinez 1996; Lepick 1998; Cook 2002; Buffetaut 2008; Brüger 1930, 86 za: Kaliński 2010, 109-110).

Chociaż działania nad Rawką i Bzurą z 1914-1915 roku, można śmiało nazwać "Ypres frontu wschodniego" (Kaliński 2010, 3, 181), to materialne i mentalne ślady po tamtych wydarzeniach na obszarze, który proponuję nazywać wschodnim krajobrazem pogazowym są niemal nieobecne, zwłaszcza w porównaniu do zachodniego. W efekcie krytycznej oceny kondycji materialnych pozostałości po Pierwszej Wojnie Światowej, stwierdzić można, że: (1) podczas gdy w Belgii mają one realny wpływ na kształtowanie wspólnot pamięci i wspólnot interpretacyjnych, to (2) w Polsce, sprawczość po-wojennych pozostałości jest niewielka.

Refleksja nad funkcjonowaniem materialnych pozostałości, prowadzi nas do pytania o interakcje archeologii polskiej z pamięcią o Wielkiej Wojnie i materialnymi jej pozostałościami. Wydaje się, że stanowią one odzwierciedlenie „zaburzeń” w doświadczaniu upływu czasu, lecz co jeszcze ciekawsze mogą ten „upływ” (pewnym zakresie) kierunkować! Na przykład: specyfikę wątłych odniesień materialnych, emocjonalnych (w tym pamięciowych) do Wielkiej Wojny tłumaczyć można procesem nakładających się na siebie powodów „zamulania” strumienia pamięci. Zasadnicze z nich to: wyjściowo, problematyczny i złożony kontekst historyczny w którym wojna ta dotknęła ziem Polski (brak niepodległości państwa i rozdarcie narodu między zaborcami) oraz następstwa społeczne, polityczne, ekonomiczne i historiograficzne (np. większe znaczenie wojny polsko-bolszewickiej niż Wielkiej Wojny, a potem radykalne doświadczenia II wojny światowej), które nie sprzyjały utrwalaniu pamięci o „poprzedniej wojnie”. Również jednak, „zamulenie” wynika ze stuletniego intensywnego procesu zubażania materialnych pozostałości po wojnie. Konfrontuje nas to z pytaniami o stopień uczestnictwa archeologii w Polsce w uzupełnianiu historii Wielkiej Wojny oraz o poznawcze i społeczne następstwa jej zaangażowania w tą problematykę. 
W sensie epistemologicznym, również w Polsce, archeologia jako dyscyplina, która stopniowo zakreśliła „przestrzeń prób” na ponad 4 miliony lat (Hensel 1973, 23, 171; Tabaczyński 1987; Cyngot, Zalewska 2012, 193-5), jest gotowa do podjęcia kompleksowych analiz stanowisk pierwszo wojennych. Pomimo, że wciąż, dla niektórych archeologów nie jest oczywiste, że archeologia na trwałe i z poważnych powodów ściśle zazębiła się z dyskursem pamięci (Olsen 2010, 107-128; Moshenska 2010; Borić 2010, Zalewska 2012a) oraz z problematyką bliskiej przeszłości, to w praktyce badawczej przejawy poszerzania granic archeologii należy uznać za powszechne. Wynika to z akceptowalnych aktualnie norm i zasad metodologicznych i metodycznych (tu głównie z wytycznych do prowadzenia prac przedinwestycyjnych). Dzięki temu, coraz częściej raporty i sprawozdania archeologiczne mogą dostarczyć osobom zainteresowanym archeologią bliskiej przeszłości (w tym, wydarzeniami sprzed stu lat) interesującej lektury. Ograniczę się tu do skomentowania treści sprawozdań archeologicznych, z obszaru działań wojennych nad Rawką i Bzurą:

W 2008 r. prowadzone były na trasie autostrady A2 przedinwestycyjne prace wykopaliskowe. Spośród 17 obiektów o charakterze antropogenicznym (od neolitu, poprzez epokę brązu po okres wpływów rzymskich) odnotowano „obiekty związane z budową umocnień obronnych w czasie I Wojny Światowej”. Poddano je skrupulatnej analizie archeologicznej i dokonano charakterystyki funkcjonalnej. Obiekty zostały zinterpretowane jako: „transzeja komunikacyjna”, „okop strzelecki”, „schron bojowy, bądź ziemianka”. Odnotowano „brak przedmiotów charakterystycznych dla użytkowanych urządzeń obronnych tego typu (nagromadzenia tusek karabinowych, oporządzenia wojskowego, przedmiotów użytkowych, śmietnisk itp.)”. W wypetnisku ,znaleziono jedynie trzy, niewystrzelone, rozbrojone tuski od pocisków karabinowych oraz kilka ołowianych kulek szrapnelowych” (fragmenty kursywą i w cudzysłowach za: Wyczółkowski, Cyngot 2008 dziękuję autorom za udostępnienie mi raportu przed jego publikacją). Godne podkreślenia jest to, że sprawozdanie zawiera bogate odniesienia do: (a) kontekstu (historycznego i społecznego) wydarzeń związanych z użyciem broni chemicznej na tym terenie; (b) okoliczności wizyty na terenie pola bitwy pomysłodawcy użycia gazów bojowych prof. Fritza Habera; (c) wielkości strat ludzkich pierwszego skutecznego użycia chloru jako gazu bojowego zarówno pod Ypres, jak i pod Bolimowem w 1915 roku; (d) miejsc pochówków żołnierzy (np. do „bratnich mogił”, tj. zbiorowych mogił w Wiskitkach, Miedniewicach i Guzowie); (e) bolesnych skutków działań zbrojnych dla lokalnej ludności cywilnej. Odnotowano również, wykazując się przy tym wrażliwością na kwestie stosunku do przeszłości w przeszłości, że w okresie międzywojennym (w którym powstały trzy mauzolea: w Huminie, JoachimowieMogiłach, Złotej) dbano o cmentarze wojenne. Zaś po II Wojnie Światowej o większości cmentarzy zapomniano, aż po lata 8o. gdy kilka z nich zostało uporządkowanych np. w Bielicach, w Ruszkach i w Bolimowskiej Wsi (Wyczółkowski, Cyngot 2008). Podjęte zagadnienia, stanowiące wartościowy element sprawozdania archeologicznego można określić jako wynikające z wnikliwej kwerendy historycznej oraz z wrażliwości (sic!) badaczy na problemy materialnych pozostałości bliskiej przeszłości. 
Nie zawsze jednak kwerendy archeologów są wystarczające. Obrazują to m.in. Wyniki archeologicznych badań ratowniczych przeprowadzonych w gm. Wiskitki. Ograniczę się tu do analizy pierwszego zdania części 3.1.3., Wyników... gdzie czytamy: „Po zdobyciu Sochaczewa przez XXV korpus niemiecki 23 grudnia 1914 roku starcia toczyty się na lewym brzegu Bzury od Łowicza aż do ujścia rzeki” (Ziemska (red.) 2010, 46). Tymczasem: 1. Sochaczew nie został zdobyty, aż do końca działań nad Rawką; 2. przywołany w sprawozdaniu XXV korpus niemiecki nigdy nawet nie otarł się o Sochaczew (por. Martinez 1996, 26; Haber 2002, 30; Kaliński 2010, 9-12). Tego typu „aplikacje” nie pogłębionej wiedzy w kontekście badań „prahistorycznych” stanowisk, należy uznać za szkodliwe i wymagające głębszej diagnozy.

O ile powyższe sprawozdania można uznać (ze skrajnie różnych powodów) za wyjątkowe, to jako reprezentatywne dla bieżącej sytuacji i kondycji archeologii I Wojny Światowej w Polsce mogą być uznane treści, zawarte w Wynikach badań archeologicznych przeprowadzonych $w$ sezonach 2005-2007 w Bolimowie na stanowisku 9, pow. skierniewicki, woj. Łódzkie (Świątkiewicz 2005-2006). W tym wypadku, również w ramach prac przedinwestycyjnych przebadano, zlokalizowane w 1983 roku w trakcie badań AZP 60-58/9 i określone wówczas jako wyłącznie „wczesno- i późnośredniowieczne” (sic!) wielokulturowe stanowisko. Rozpoznano tam liczne ślady, począwszy od epoki brązu a skończywszy na pozostałościach z XVI i XIX - wiecznych oraz reliktach z I i II wojny światowej. W budzącym uznanie dla wdrożonej metodyki badań raporcie odnotowano m.in., że „na przetomie 1914/1915 r. oraz w 1944 r. teren ten stanowit pola bitew I i II wojny światowej”, po których pozostały „pozostałości umocnień polowych (ziemnych i drewniano-ziemnych)”. Zostały one w raporcie zdefiniowane jako "obiekty nietypowe dla badań archeologicznych": "Ich eksploracja połaczona była z pewnym ryzykiem dla pracowników i mogła być realizowana tylko w ścistej wspótpracy z nadzorem saperskim. Czynniki te komplikowały organizację i zwalniały tempo prac. Nie zawsze można było też zastosować standardowe techniki eksploracyjne ze względu na zasięg, kształt i układ tych obiektów”. Za szczególnie istotną w kontekście niniejszego artykułu uznać należy puentę tego raportu: „Dwudziestowieczne polowe fortyfikacje nie stanowity do tej pory przedmiotu zainteresowań archeologów, choć pod każdym względem sa one obiektami równorzędnymi z innymi dziełami militarnej architektury i ogólnie rzecz biorąc stanowiskami archeologicznymi. Sprawa ta wymaga głębszej refleksji metodologicznej" (Świątkiewicz 2005-2006, 203-204). Jest zatem potrzeba ustalenia kompleksowej metodologii adekwatnej zwłaszcza w sytuacjach, w których materialne pozostałości bliskiej przeszłości przenikają się z pradziejowymi tworząc tak charakterystyczne dla stanowisk archeologicznych palimpsesty (Bailey 2007, 203208; Olivier 2008, 193 i nast.; Lucas 2010, 350 i nast).

Bliska przeszłość, a z nią teraźniejszość, w sensie materialnym jest niczym innym, jak sekwencją archeologiczną, która naturalnie dokłada się do wszystkiego co ją poprzedzało. Zarówno w sensie materialnym jak i mentalnym. Tak realizuje się, moim zdaniem kluczowa dla zrozumienia archeologii, głęboko antropologiczne znaczenie „palimpsestowej” na- 
tury rzeczywistości. Relikty I czy II wojny światowej i ich różnego typu koincydencje z badaniami archeologicznymi należy uznać za powszechne, czemu trudno się dziwić mając świadomość historii naszego kraju. Niemal każde stanowisko archeologiczne ma poniekąd palimpsestowy charakter. „Długie trwanie” odbija się na wszystkich branych tu pod uwagę stanowiskach. Są one palimpsestami w podwójnym sensie: stratygraficznym i metaforycznym, bo antropologicznym. Nakładanie warstw osadniczych i efektów procesów podepozycyjnych jest clue z jakim poznawczo mierzy się archeolog.

Brytyjski archeolog konfliktu, Nicholas J. Saunders przekonuje, że żaden inny przedmiot badań archeologii nie jest tak poruszająco antropologiczny, jak Wielka Wojna i inne konflikty XX wieku „Mają one potencjał łączenia pokoleń i różnych podmiotów (naukowców, studentów, osoby zwiedzające pola bitewne i wszystkich, którzy pragną zrozumieć straty i wysiłki ludzkie, składające się na tworzenie świata, w którym żyjemy" (Saunders 2004, 30 -31; 2007). N. Saunders (2012) podkreśla też prospektywny charakter wyników działań w przestrzeni „archeologii konfliktu” wskazując wartość i znaczenie nie tylko materialnych pozostałości zniszczeń wojennych, ale także wciąż odmładzanych zabytków i aktualizowanych krajobrazów upamiętnień. Przejawem tych ostatnich są nowe przedsięwzięcia muzeologiczne, angażowanie mass-mediów w propagowanie wiedzy o przeszłości, nowe koncepcje odnoszące się do „dziedzictwa wojny” (war heritage) i rozkwit wielomilionowych inwestycji turystycznych w miejscach związanych z konfliktem. Co szczególnie istotne: poza motywami ekonomicznymi, za kluczowe dla następstw zajmowania się „archeologią konfliktu” wskazywane są filozoficzne, czy wręcz duchowe uzasadnienia „przywracania ziemi” pod uprawę (AZ: i dodam od siebie „przywracania” jej praktykom upamiętniania tam, gdzie wydaje się to zasadne, czy wręcz konieczne). Jednak nawet te wzniosłe cele nie usprawiedliwiają „kopania” tych wyjątkowych miejsc, bez silnych i stosownych w danym czasie i miejscu motywacji etycznych i merytorycznych. Konieczne jest też spełnienie wymagań formalnych i prawnych. Badania stref konfliktu nie powinno być traktowane jako rozrywka, czy poszukiwanie skarbów pod przykrywką archeologii (Excavating battle - zone conflict sites is not the entertainment, and should not be treasure hunting dressed up as archaeology) (Saunders 2012, ix, xiv).

Proponuję tu, by traktować sugestie i doświadczenia zachodnioeuropejskich kolegów zajmujących się „archeologią konfliktu” jako pomocne w tworzeniu antidotum na „czarną archeologię” również na „skrwawionych ziemiach” (określenie użyte przez Timothy Snydera dla opisania Wschodniej i Środkowowschodniej Europy). Wiele skłania do (po)traktowania - jako „poligonu” archeologii stosownej i stosowanej - archeologii bliskiej przeszłości, w tym „archeologii konfliktu”. Nie ogranicza się ona do badania pól bitewnych, lecz odnosi się do wszystkich aspektów danego konfliktu i w którego polu równie istotne co miniony konflikt sam w sobie, są jego wielowymiarowe i ciągle zmienne następstwa oraz, co wydaje się nie mniej godne uwagi - wszystko to co konflikt ten poprzedzało i co po nim następowało i co utrwaliło się w materialnym archiwum ziemi. 


\section{„MILITARIA”: MIĘDZY „CZARNA”” ARCHEOLOGIA I ARCHEOLOGIA „STOSOWANA”}

W miarę upływu czasu, ciata zapadają się coraz glębiej, a zainteresowanie pamiątkami wojennymi przyspiesza - skonstatowal jeden z czołowych badaczy Archeologii Pierwszej Wojny (Saunders 2002, 101). Postępująca intensyfikacja grabieży miejsc, w których odnaleźć jeszcze można relikty działań zbrojnych XX wieku, jest problemem ogólnoeuropejskim. Szczęśliwie, przynajmniej w Belgii, zainteresowanie militariami nie wyczerpuje się (zwłaszcza na terenie byłego Frontu Zachodniego) wyłącznie w „czarnej archeologii” - dostrzegalne są liczne inicjatywy łączące w pełni profesjonalnie zadania poznawcze i marketingowe, konserwatorskie i menadżerskie (CRM), akademickie i pozaakademickie (np. The European Group for Great War Archaeology. No Man's Land, założona w 2003 r.). Nie będzie jednak przesadą stwierdzenie, że również archeologię belgijską, analogicznie do archeologii polskiej trawi "problem czarnej archeologii”, w której polu znajdują się również relikty Wielkiej Wojny.

Zjawisko „czarnej archeologii”, czyli nielegalnych wykopalisk, często powiązanych z handlem zabytkami narasta. Szacuje się, że w Polsce jest ok. 100 ooo detektorystów (Trzciński 2010), podczas gdy 5 lat temu ich liczbę określano na około 35 ooo. Odnotowuje się przy tym niemal całkowity brak problemu grabieży materialnych dóbr kultury w okresie komunistycznym (choć wg znawców tematu problem ten istniał również wówczas, ale nie został dotychczas zbadany). Jako punkt zwrotny dla czarnej archeologii Polsce wskazuje się lata 1993/94 (Cultural Heritage Cooperation... 2005, 29- 32).

Problem tzw. „detektorystów”, „poszukiwaczy”, ,szabrowników”, nie jest traktowany w powszechnej opinii publicznej jako znaczący czy istotny (zob. Saunders 2007, 9-17; Trzciński 2010; Ulst 2010). Utrudnia to skuteczne przeciwdziałanie temu procederowi. Przyczyniają się do tego: (a) niedoskonałe rozwiązania legislacyjne; (b) racje pragmatyczne, będące w konflikcie z etycznymi lub/i ekonomicznymi założeniami ochrony dziedzictwa archeologicznego; (c) nieoczywistość (poznawcza, etyczna, estetyczna) uwarunkowań i następstw traktowania materialnych pozostałości po konfliktach $\mathrm{XX}$ wiecznych jako przedmiotu badań lub jako np. muzealiów; (d) niechęć archeologów, regionalnych konserwatorów i muzealników do przejęcia odpowiedzialności również za XX wieczne dziedzictwo materialne oraz do obowiązków wynikających z ich zachowania i (po)traktowania np. jako eksponatów etc. Na niekorzyść działa również (e) relatywna bierność środowiska archeologów i brak wspólnego ogólno-środowiskowego stanowiska np. w kwestii współpracy z „archeologami wolontariuszami” / „archeologami amatorami” (czyli tymi, którzy chcą zachować dziedzictwo i kierują się szlachetnymi pobudkami). Wynikają z tego zarówno poważne napięcia między archeologami i pogłębiająca się dyskredytacja ich społecznej pozycji oraz niemoc w kwestii prewencyjnych działań dydaktycznych. Ponieważ poczyniono już wiele istotnych uwag w tej materii (Brodie et al. 2000; Bursche 2001a-b; Szpanowski 
1999, 2001a,b; Trzciński 2010) ograniczę się tu do zdefiniowania nielegalnej archeologii, a następnie naszkicuję jej relacje z archeologią I wojny.

„Czarna archeologia” oznacza wszystkie pojedyncze lub grupowe działania, które związane są z nielegalnymi i nienaukowymi wykopaliskami, z niszczeniem i sprzedażą dziedzictwa archeologicznego pochodzącego z nielegalnych lub właściwych wykopalisk, ale nie ogranicza się do samych poszukiwań, lecz zawierają się w niej także wszelkie wstępne badania, nawiązywanie kontaktów i informacji ułatwiających proceder oraz wszelkie następstwa tj. czyszczenie, ingerencja w materię zabytkową, szukanie kupców, oferowanie do sprzedaży i sprzedaż (Ulst 2010, 154). Traktując taką złożoną definicję „czarnej archeologii” jako trafnie charakteryzującą zjawisko z którym mamy do czynienia również w Polsce, konieczne wydaje się jej uzupełnienie. Jako elementy „czarnej archeologii” winny być traktowane również pośrednie przyczyny (poprzedzające dany proceder zaniedbania, które do niego dopuściły, bądź doprowadziły, w tym np. krótkowzroczne decyzje konserwatorów, nieodpowiedzialne i nieetyczne zachowania archeologów, czy ignorancja pracowników muzealnych) oraz dalekosiężne następstwa (moralne, epistemologiczne, etyczne) wynikające z tego procederu.

Analiza zjawiska „czarnej archeologii” to trudne zagadnienie zwłaszcza, gdy jego obserwacji towarzyszy świadomość, że jak w przypadku Polski, w środowiskach odpowiedzialnych za ściganie, i penalizację tego typu przestępstw, istnieje duża grupa akcjonariuszy tego nieszczęsnego hobby. Opinię tą buduję na sądach tych, którzy mieli do czynienia z prokuratorami, pogranicznikami, policjantami i żołnierzami (czynnymi zawodowo i już emerytowanymi) zasilającymi grupę "poszukiwaczy”, w znaczący i bardzo brzemienny w skutki sposób. Jako lobby wspierają się oni (co rzutuje także na ludzi spoza ww. grup zawodowych) promując opinię, że jest to niewinna działalność rozrywkowa (sposób „odreagowania codzienności”). Ponieważ nie sposób wskazać konkretnych osób bez dowodów, wydają się oni zatem w znaczącym stopniu bezkarni. W celu zaradzenia temu zjawisku, a zwłaszcza rozpoczęcia procesu „resocjalizacji” uczestników tego procederu, konieczne wydają się szczegółowe badania interdyscyplinarne, mające na celu rozpoznanie motywacji, okoliczności i następstw działań poszczególnych ludzi z kręgu bardzo zróżnicowanej grupy „wykrywaczowców”, „detektorystów”, „pasjonatów przeszłości”, „rabusiów”, „grabieżców”, „Szabrowników”. Tego typu zamysł wymyka się kompetencjom archeologa. Ponieważ jednak zjawisko to nie stało się dotychczas w naszym kraju przedmiotem badań socjologów czy kulturoznawców, można więc zakładać (że jeśli tak się nie stanie) to środowisko archeologiczne zmuszone będzie dokonać takiej diagnozy samodzielnie (oczywiście ze wsparciem osób kompetentnych). Wyniki i następstwa tego typu badań zbliżą nas do archeologii w pełni stosow(a)nej.

Pomocne w zobrazowaniu teoretycznych założeń archeologii stosow(a)nej, może być przywołanie konkretnej oddolnej inicjatywy, która zawierała w sobie potencjał bycia praktyczną jej realizacją: w sierpniu 2012, wokół krateru po wybuchu miny artyleryjskiej z I 
wojny światowej, w lesie nad rzeką Rawka, nastąpił „pierwszy bezinwazyjny etap badań” z użyciem metod archeologicznych. Celem badań było: doprowadzenie do przeprowadzenia w pełni profesjonalnych badań archeologicznych; przywrócenie pamięci o działaniach wojennych nad Rawką i Bzurą w 1915 roku oraz zebranie materialnych pozostałości po pierwszo-wojennych działaniach i przyszłe ich zademonstrowanie $\mathrm{w}$ zarejestrowanym (również z oddolnej lokalnej inicjatywy) Bolimowskim Muzeum Techniki Militarnej i Użytkowej. Badania odbyły się z udziałem członków grupy Stowarzyszenie EksploracyjnoHistoryczne „grupa Łódź” i pod nadzorem archeologa z Uniwersytetu Łódzkiego (dr Piotra Nowakowskiego). Inicjatorzy liczyli na możliwość wyeksplorowania zasypanych przez wybuch transzei w których, w świetle niemieckich kronik pułkowych, zasypanych zostało wraz z ekwipunkiem wielu żołnierzy. Badania przyniosły znaczną ilość drobnych przedmiotów związanych z toczącymi się tu przed stu laty działaniami wojennymi. $Z$ poszukiwaniami łączona była nadzieja na odtworzenie epizodów i realiów zmagań, które nie zostały zarejestrowane w źródłach historycznych. Wydarzenie miało charakter mikro lokalny i odbiło się echem jedynie w lokalnej gazecie skierniewickiej i w pamięci uczestników badań. Delimitacja obszaru który inicjatorzy tj. członkowie lokalnego „Stowarzyszenia Inicjatywa Ziemi Bolimowskiej" chcieli wskazać jako wart w pełni profesjonalnych badań archeologicznych nie powiodła się.

Mimo sprzyjających okoliczności tj.: (a) znaczącego zaangażowania pomysłodawców i uczestników badań; (b) faktu, że są formalne podstawy do tego, by otoczyć krater opieką konserwatorską (gdyż obiekt ten podlega notorycznie niszczeniu i jest traktowany zarówno jako wysypisko śmieci przez okolicznych działkowiczów jak i jako przestrzeń nielegalnej eksploracji szabrowników); (c) istotnych przesłanek merytorycznych do podjęcia badań (bardzo ograniczone dane na temat ataków gazowych na froncie wschodnim i działań je poprzedzających może stanowić wynik intencjonalnych działań mających na celu zatarcie, a przynajmniej zmarginalizowanie tego „epizodu” przez Niemców) - wyniki tych badań nie doprowadzily na razie do obranych przez inicjatorów celów. Lokalna konserwator odmówiła zgody na dalsze badania w planowanym przez „Stowarzyszenia Inicjatywa Ziemi Bolimowskiej” trybie. Równie istotnym aspektem tego „doświadczenia” był fakt, że jego uczestnicy potrzebowali archeologów głównie po to, by sformalizować i usankcjonować swoje działania. Nie liczyli na wsparcie merytoryczne z ich strony. Należy tu zaznaczyć, że uczestnicy pierwszego etapu badań wykazywali się rozległą znajomością problemu i jedynie, jeśli chodzi o metodykę badań byli otwarci na wszelkie sugestie. Jako obserwator tego wydarzenia odniosłam wrażenie, że dokonała się w jego trakcie symptomatyczna zamiana kompetencji, archeolodzy zamienili się pozycjami z tymi, których określano mianem widzów/ odbiorców wiedzy archeologicznej. Umniejsza to poniekąd „autorytet archeologii” i co znacznie bardziej dotkliwe, osłabia szanse na wspólnotową ochronę materialnych pozostałości po XX wiecznych konfliktach.

Moim celem nie jest przekonywanie, że każdy kopać może, trochę lepiej, lub trochę gorzej... Nie poddaję tu w wątpliwość, że to wciąż zadaniem archeologów jest szczegółowe 
rozpoznanie i zadokumentowanie lub jeśli to konieczne, wydobywanie z ziemi w sposób w pełni profesjonalny, śladów przeszłości i wkomponowywanie ich w aktualne sieci skojarzeń, znaczeń, celów. Bliskie mi jest stanowisko zawarte w Deklaracji polskiego środowiska archeologicznego $w$ sprawie detektorystów z 14 maja 2012 r., w którym archeolodzy głęboko zaniepokojeni m.in. niszczeniem coraz większej liczby stanowisk archeologicznych przez amatorskie, sprzeczne z prawem rozkopywania przez osoby posługujące się elektronicznymi urządzeniami do wykrywania metali, stwierdzili m.in., że: „Dziedzictwo archeologiczne jest delikatnym, narażonym na łatwe zniszczenie, nieodtwarzalnym i skończonym zasobem kulturowym ludzkości”, którą, jako własnością wspólną społeczeństwa, opiekują się i zarządzają we wspólnym interesie służby konserwatorskie, wspierane wiedzą przez archeologów i instytucje naukowe, muzealne i konserwatorskie (Art. 1, za: www. snap.org.pl).

Szczególnie interesująco brzmi wyartykułowane w powyższym zapisie odniesienie do wspólnego interesu społecznego, w odniesieniu do materialnych pozostałości Wielkiej Wojny. Nie odgrywały one dotychczas znaczącej roli w przestrzeni pamięci kulturowej Polaków, można więc postulować, że ich ochrona i badanie ich specyfiki nie leży w interesie społecznym. Zaryzykuję wręcz stwierdzeniem, że w wyniku braku poznawczego (profesjonalnego) zainteresowania nimi - nie zostało dla owych pozostałości wytworzone łożysko dla pamięci „fundacyjnej”, dlatego popadają one w niepamięć. Są elementem „dryfującej luki”. Nie są jednak niczyje i nieprzydatne. Ponieważ są. Fakt, że na byłym froncie wschodnim status materialnych reliktów Wojny Totalnej jest wątpliwy, nie sprzyja jednak ich trwaniu w czasie.

Tymczasem, w Europie Zachodnie (tu skupiam się na Flandrii), pomimo, że materialne pozostałości po Pierwszej Wojnie nabrały formalnej rangi „znalezisk archeologicznych” relatywnie niedawno - to zawsze były one znacząco obecne w przestrzeni publicznej. Co za tym idzie ich ochrona i zainteresowanie nimi leżały w interesie społecznym. W efekcie zmian legislacyjnych i nadania tym rzeczom również rangi poznawczej, stały się one aktualnie przedmiotem uwagi i troski nie tylko „archeologów amatorów”, ale również powołanej specjalnie w tym celu zinstytucjonalizowanej dyscypliny. Od 1992 do 2003 roku zachodni, krajobraz pogazowy badali głównie nie-archeolodzy. Tzw. Diggersi za zgodą właścicieli pól i lasów odnajdywali materialne pozostałości Wielkiej Wojny w porozumieniu z: lokalnymi służbami konserwatorskimi (Belgium's Institute for Archaeological Heritage, IAP), z lokalnymi muzeami (również z kluczowym państwowym In Flanders Field Museum w Ypres), z policją i saperami (w razie odnalezienia niewypałów) oraz z organizacjami odpowiedzialnymi za pochówki tj. Commonwelth War Graves Commission (w razie odnalezienia szczątków ludzkich) (Saunders 2007, 12-13; Smith 1999; Dewilde et al. 2004).

Co szczególnie istotne dla prowadzonej tu analizy - najintensywniejsze działania Diggersów skupiały się na obszarze, który był świadkiem niemieckich ataków gazowych w 1915 roku. Na przestrzeni 100 lat był on poddawany stosunkowo niewielkim przemianom agrarnym i industrialnym. Do dziś doceniany jest (choć nie jednogłośnie i w sposób nie pozbawiony kontrowersji, zwłaszcza ze strony brytyjskich komentatorów) wkład poszu- 
kiwaczy amatorów w odnalezienie wielu unikalnych pozostałości, w zachowanie materialnego patrymonium flandryjskich pól bitewnych, a tym samym ich udział w podtrzymywanie pamięci o wydarzeniach sprzed stu lat. Podkreślana jest ich ogromna i drobiazgowa wiedza na temat zdarzeń, które miały tam miejsce trakcie konfliktu i po jego zakończeniu. Efekty i znaczenie ich działań są dziś eksponowane w prywatnych i państwowych muzeach, a część z nich, co chyba nieuniknione w takiej sytuacji, zasila prywatne kolekcje i giełdy, głównie internetowe. Nawet jeśli przyjąć, że większość flandryjskich poszukiwaczy miała i ma szlachetne zamiary, to odnotowuje się tam także znaczącą plagą szabrowników: Są wśród nich tzw. hieny cmentarne (battlefield scavengers), które bez żadnych skrupułów niszczą pochówki. Ci pozbawieni zahamowań etycznych „padlinożercy” szukają rzeczy związanych z Pierwszą Wojną bezczeszcząc zwłoki swoich przodków i niszcząc ogólnoeuropejskie dziedzictwo (Saunders 2007, 11-12).

Między innymi, to właśnie narastający problem nielegalnych poszukiwań militariów przez detektorystów, obok zniszczeń powodowanych przez lokalne inwestycje oraz konieczności przeprowadzenia prac związanych z budową autostrady A - 19 przez obszar pobitewny Ypres Salient (zwłaszcza przez Pilckem Ridge, które było świadkiem dramatycznych strat podczas Trzeciej Bitwy po Ypres w 1917) spowodowały, że w 2002 roku IAP rozpoczął szerokopłaszczyznowe badania archeologiczne. Przedsięwzięcie to unaoczniło szybko skalę problemu. Dlatego podjęto decyzje skutkujące stworzeniem pierwszego w świecie działu archeologicznego poświęconego wyłącznie archeologii Pierwszej Wojny.

W 2003 w Ypres Minister Paul van Grembergen ogłosił otwarcie instytucji pod nazwą Department of First World War Archaeology. Jest to oddzial flandryjskiego instytutu dziedzictwa (Institute for the Archaeological Heritage of the Flemish Community (IAP), wspierany przez: władze lokalne (Province of Western Flanders), flandryjskie uniwersytety oraz belgijską Army's Service for the Disposal and Demolition of Explosives (DOVO). Zasadnicze cele tego oddziału to: (a) podejmowanie badań archeologicznych, inwentaryzacji i konserwacji znalezisk oraz zarządzania wszystkimi aspektami związanymi z dziedzictwem I Wojny Światowej zwłaszcza we Flandrii; (b) koordynowanie i nadzorowanie licznych i różnorodnych inicjatyw i działań oraz wspieranie stowarzyszeń, instytucji (np. muzeów, biur turystycznych) i osób prywatnych (np. historyków, amatorów wykopalisk) zainteresowanych upamiętnianiem Wielkiej Wojny; (c) stworzenie forum naukowego, które byłoby w stanie zebrać rozproszoną dotychczas wiedzę na temat I wojny i dysponować wiedzą ekspercką (pomocną profesjonalistom i amatorom) w tym zakresie (Dewilde et al. 2004).

Wszystkie te cele znajdują uzasadnienie w postawie akceptującej traktowanie archeologii nie tylko, nawet nie przede wszystkim jako dyscypliny naukowej zajmującą się odkrywaniem pozostałości z przeszłości i ich opisem, wyjaśnieniem, interpretacją czy oceną, ale także jako działalności społeczno-kulturalnej, która dostarcza argumentów, znaczeń, sensów, pobudek do bieżącej komunikacji kulturowej. Tego typu aktywności z udziałem archeologów wpisują się w diagnozę Richarda Rorty’ego, że poznanie jest kwestią nie tyle 
właściwego rozumienia rzeczywistości, co zdobywania nawyków w celu poradzenia sobie z nią (Rorty 1999). Komentująca tą opinię Ewa Domańska, zachęca do tego, by proponować takie narzędzia badawcze i takie kategorie interpretacyjne, których wydajność mierzy się nie adekwatnością ich opisu, wyjaśnienia czy przedstawiania przedmiotu, ale efektywnością powodowania zmian i budowania „łożyska dla przyszłości” (Domańska 2012, 77).

Takim „łożyskiem” może być archeologia stosowana, przez którą rozumiem taką archeologię, która reaguje zmianami na impulsy zewnętrzne w sposobach jej uprawiania. Kluczowymi jej elementami są: z jednej strony obowiązek zachowania profesjonalnego charakteru metod badawczych, z drugiej zaś, poczucie odpowiedzialności archeologów za poziom świadomości i wrażliwości historycznej różnych grup społecznych. Za istotne w archeologii stosowanej należy uznać pozytywne nastawienie do oddolnych inicjatyw badawczych oraz docenianie aktywności amatorów, wolontariuszy i profesjonalne wspieranie ich działań.

Jeśli przyjąć, że archeologią stosow(a)ną będzie taka archeologia, która spełnia wszystkie założenia i oczekiwania (metodyczne i metodologiczne) uznawane za optymalne w danym czasie i miejscu przez profesjonalną wspólnotę archeologów, która przyczynia się do „poznania” lub do „skonstruowania” wielowątkowych interpretacji minionej rzeczywistości poprzez pozostałe po niej materialne pozostałości i która znajduje uznanie i zrozumienia społeczeństwa któremu przedstawiane są wyniki profesjonalnych badań archeologicznych - to Department of First World War Archaeology, działający we współpracy ze stowarzyszeniami archeologów profesjonalnych i amatorów oraz szerokim gronem międzynarodowych współpracowników jest jej przejawem.

Archeologia stosowana (applied archaeology) klasycznie definiowana jest jako odnosząca się do wszelkiego typu zastosowań badań archeologicznych i ich wyników w celu rozwiązywania współczesnych ludzkich problemów, np. zagadnień, które dotyczą a. zarządzania zasobami dziedzictwa kulturowego, b. rozwoju turystyki, c. kształtowania dynamicznej relacji człowiek / środowisko, d. edukacji, której celem jest przekonanie społeczeństwa do zasadności troski o dziedzictwo archeologiczne etc. Naczelnym jej zadaniem jest troska o kompatybilność z bieżącymi potrzebami społecznymi (zob. Downum, Price 1999, 227; por. też Gillespie 2008). Analogie dla tego typu podejścia znajdujemy w dotychczasowych doświadczeniach historii stosowanej (Kelly 1978; Traba 2009, 2012); antropologii stosowanej (zob. m.in. Journal for Applied Anthropology in Policy and Practice), inicjatyw obywatelskich (dziennikarstwo obywatelskie, historia obywatelska), czy w zaproponowanej ostatnio przez Ewę Domańską „historii ratowniczej”). Archeologia stosowana, odchodząca od „modelu autorytarnego” (w którym reprezentanci wiedzy profesjonalnej alienują się od społeczeństwa i od jego potrzeb i skupiają się wyłącznie na własnych, traktowanych jako nadrzędne celach) ku "modelowi społecznemu" (w którym brane są pod uwagę cele wyznaczane przez społeczne dobro powszechne, zaś odbiorcy są angażowani i zachęcani do czynnego udziały w badaniach naukowych) (por. celne uwagi na ten temat Czerniak 2011), może być również traktowana jako remedium na efekty uboczne tzw. „demokratyzacji archeologii”. Jednym z takich ubocznych efektów są następstwa dostępności 
sprzętu sprzyjającego grabieży warstw kulturowych (np. wykrywaczy, georadarów). Istotny i nie zawsze sprzyjający ochronie dziedzictwa jest też przepływ informacji nieporównywalnie większy, niż 10 lat temu. Nie powinno już ulegać wątpliwości, że domeną archeologów, oprócz niewątpliwie istotnych badań pierwotnego etapu procesu społeczno-kulturowego winny być również kompleksowe i systematyczne działania edukacyjne i prewencyjne, również w kontekście już zdiagnozowanych przypadków „czarnej archeologii”.

Bardzo liczna i wciąż w Polsce powiększająca się grupa osób z kręgu „czarnej archeologii” zakłada, poniekąd zasadnie, że są jedynymi zainteresowanymi odnajdywaniem, kolekcjonowaniem i interpretowaniem materialnych pozostałości bliskiej przeszłości (zwłaszcza militariów, w tym śladów Wielkiej Wojny). Dopóki archeolodzy nie zmienią swej postawy wobec pozostałości bliskiej przeszłości - detektoryści będą się utwierdzać w swoim przekonaniu m.in. (1) o „misyjności” tego co robią (,ratujemy przed całkowitym rozkładem, to co jeszcze zostało z ważnych wydarzeń XX wieku”); (2) o „niewinności” $i$ „niskiej szkodliwości” swoich działań („nikomu niczego nie odbieramy, szukamy tego, czego nikt już oprócz nas nie chce znaleźć”). Zarówno bierność jak i skupienie na własnych wyobrażeniach o tym, co słuszne są brzemienne w nieodwracalne skutki.

\section{WNIOSKI. STOSOWNOŚĆ I STOSOWALNOŚĆ ARCHEOLOGII}

Dotychczasowe rozpoznanie problematyki tu szkicowanej każe mi zakładać, że znaleziska z czasów I Wojny Światowej, ich społeczne reprezentacje oraz sposoby doświadczenia kontaktu z nimi są lub mogą być szczególnie interesujące, zarówno dla archeologii bliskiej przeszłości, jak i dla archeologii uspołecznionej (applied archaeology, community archaeology, public archaeology). M.in. systematyczne badania Archeologii Wielkiej Wojny, stanowiące już formalną i zinstytucjonalizowaną domenę w Europie Zachodniej, dostarczają istotnych i inspirujących spostrzeżeń w odniesieniu do relacji: archeologia - pamięć oraz do funkcji jakie pełnią (lub mogą pełnić) materialne ślady przeszlości. Odniesienia do wydarzeń sprzed stu lat i do ich materialnych korelatów, konfrontują nas z newralgiczną i płynną granicą między „pamięcią żywą” („biograficzną”), i „pamięcią fundacyjną”, w której kreowaniu archeolodzy biorą udział.

Materialne relikty Wielkiej Wojny i nasz stosunek do nich stanowią dobry punkt wyjścia do zastanowienia się nad istotą współczesnej archeologii i nad możliwościami archeologii stosow(a)nej. Jeśli dodać do tego miażdżące starty materialne na ziemiach polskich i pod wieloma względami przełomowy charakter tego konfliktu, to całkowicie nie oczywiste wyda się nikłe zainteresowanie wydarzeniami sprzed stu lat oraz ich marginalizacja w przestrzeni publicznej i w pamięci Polaków i reszty świata.

Szczególnie interesującego pola do namysłu dostarczają przyczyny, okoliczności i następstwa (u)konstytuowania się Archeologii Pierwszej Wojny Światowej. O ile na zachodzie, 
zwłaszcza w Belgii i we Francji, możemy mówić o pro-aktywnej archeologii stosow(a)nej, o tyle w Polsce, wydaje się, że poszerzanie „przestrzeni prób”, zdaje się mieć charakter wyłącznie re-aktywny. Zakładam, że pro-aktywność wynika z ciekawości poznawczej i stymuluje do przenikania celów i interesów różnych wspólnot, zaś re-aktywność jest wynikiem kompulsywnego i wymuszonego reagowania na potrzeby społeczne i zaistniałe okoliczności (np. w kontekście badań ratowniczych czy przedinwestycyjnych). Odważę się też stwierdzić, choć może to zabrzmieć obrazoburczo, że bliższe rozpoznanie ww. zjawisk wskazuje na to, że w kreowaniu charakteru relacji archeologii ze społeczeństwem oraz w poszerzeniu pola zainteresowań archeologii, istotną rolę odgrywają, obok miłośników przeszłości, również „detektoryści” i amatorzy. W odniesieniu do reliktów z I Wojny Światowej, taka zwrotność w pełni znajduje swój wyraz w Belgii. Również jednak u nas da się dostrzec jej przejawy.

Wspólnotowej trosce o materialne pozostałości bliskiej przeszłości sprzyjają aktualne okoliczności. Np. we wspomnianej wyżej deklaracji z 14 maja 2012 r., stwierdza się m.in. „Archeologia nie jest nauką, której zainteresowania i możliwości badawcze ograniczone są do pewnego tylko okresu przeszłości. Metodami archeologicznymi badane są także miejsca i obiekty o stosunkowo krótkiej historii, np. pola bitewne z I i II wojny światowej, miejsca martyrologii, czy opuszczone miejsca produkcji przemysłowej, przynosząc ważne nowe informacje, niemożliwe do uzyskania innymi metodami” (art. 7, za: www.snap.org.pl). W praktyce jednak, to - choć wymuszone przygnębiającymi okolicznościami, to jednak postępowe i precyzyjnie wyartykułowane - stanowisko archeologów jest (zbyt) często podważane przez urzędników decydujących o tym, co ma zostać uznane za zabytek i o co należy się zatroszczyć. Również, pośrednio i bezpośrednio artykułowana niechęć archeologów do materialnych pozostałości bliskiej przeszłości skutkuje popadaniem tych śladów w nicość, bądź w przestrzeń szabru i czarnego rynku. Nie zdołam tu niestety określić procentowego udziału XX-wiecznych militariów i innych znalezisk związanych z nowożytnością i współczesnością na czarnym rynku, ale udział ten jest na tyle znaczący, że nie może być ignorowany przez środowisko archeologiczne.

Postawa akceptująca postrzeganie archeologii m.in. jako zaczynu ożywiania pamięci (społecznej) o tym, co (niedawno) minione, w tym „pamięci biograficznej” oraz jako elementu szeroko rozumianej działalności kulturotwórczej, zachęca do tego, by postrzegać materialne relikty bliskiej przeszłości jako niezbędny przedmiot „lektury palimpsestowej” (określenie za Zygmuntem Baumanem). Zakłada ona, że odbiorca: uświadamia sobie złożoność odbieranego komunikatu; że docieka tego, co nie jest widoczne wprost oraz że dostrzega uprzedniość, a tym samym dynamikę/zmienność znaczeń łączonych z danym nośnikiem informacji np. materialnym śladem przeszłości.

Taka, dociekająca wielowarstwowości i wielogłosowości „palimpsestowa” archeologia, powinna być budowana na założeniu, że stanowiska archeologiczne i materialne pozostałości (również) po bliskiej przeszłości oraz różnego rodzaju “wykopaliska” (te w głąb ziemi i krajobrazów, w głąb tekstów i tekstur, w głąb pamięci i wyobraźni), mogą pełnić istotne role. 
Mogą się one przyczyniać do lepszego zrozumienia napięć między przeszłością - teraźniejszością i przyszłością, między pamięcią i zapomnieniem, między tekstem a teksturą tego co nam z przeszłości pozostało. Sprzyjać temu może zwracania uwagi na wszelkie przejawy wtórnego eksploatowania wiedzy archeologicznej, „pamięci materii” i materialnych śladów przeszłości, zarówno te konstruktywne i budujące jak i te mroczne, amoralne i dyskusyjne (vide perspektywa archeologii drugiego stopnia oraz archeologï materii reaktywowanej (AMR) - koncepcje te przedstawiam m.in. w Zalewska 2009, 2012; por. też Olivier 2008; Moshenska 2010; Borić 2010).

Interakcje archeologii ze społeczeństwem (w tym na zwrotność tej relacji, będącą przedmiotem szczególnej uwagi w tym artykule) należy wreszcie uznać za kluczowe. Nie poddaję jednak w wątpliwość, że to wciąż zadaniem i odpowiedzialnością archeologów jest w sposób optymalny wydobywać z ziemi ślady przeszłości i wkomponowywać je w aktualne sieci skojarzeń, znaczeń, celów. Zmiany społeczno-kulturowo-rynkowe sprawily jednak, że archeolodzy nie są w tym dziele osamotnieni oraz, że racje archeologów przestają być czytelne dla społeczeństwa polskiego (są oni traktowani, bynajmniej nie incydentalnie, jako „zło konieczne” czy „zbędny” $i$ „pazerny” element prac przedinwestycyjnych”). Problem ten wymaga wnikliwej analizy. Jednocześnie, coraz bardziej unaoczniany jest potencjał wiedzy archeologicznej jako przedmiotu „lektury palimpsestowej” tj. gdy odbiorca uświadamia sobie złożoność komunikatu, gdy z premedytacją docieka tego, co nie jest widoczne wprost oraz gdy zakłada uprzedniość a tym samym dynamikę/zmienność znaczeń łączonych z danym nośnikiem informacji np. śladem przeszłości. Nie ulega wątpliwości, że zasadniczy wpływ mają na to okoliczności, w jakich archeolodzy kreują obraz przeszłości i przekształcają również teraźniejszość w inną teraźniejszość.

Więcej nawet, śmiem twierdzić, że gdy archeolodzy pozostają bierni wobec materialnych reliktów bliskiej, to zostawiają pole do działania ludziom, którzy bezprawnie łupią materialne pozostałości po wojnie.

Idąc tropem dotychczasowych obserwacji i przemyśleń, staram się stworzyć teoretyczne ramy perspektywy, którą określam mianem archeologii stosow(a)nej tj. zgodnej z poznawczymi i etycznymi standardami archeologii i jednocześnie wrażliwej na potrzeby społeczne. Wsłuchiwanie się i bieżące reagowanie na te potrzeby nie jest zadaniem łatwym, a z uwagi na tendencje do trywializacji (por. Kokowski 2010), urynkawiania (por. Pawleta 2011) czy niszczenia dziedzictwa archeologicznego - bywa frustrujące. Nie da się jednak pomijać czy ignorować intencji i działań interesariuszy, począwszy od fascynatów historii XX-wiecznych wojen, poprzez kolekcjonerów militariów, a skończywszy na szabrownikach i handlarzach. Mają one znaczący wpływ na:

(a) realne poszerzanie zakresu badań archeologicznych;

(b) na ksztaltowanie orientacji temporalnej i pamięci wspólnot i jednostek;

(c) kwestie poczucia ciąglości pamięci o tym co minione, ale wciąż w nas;

(d) stosunek do zmarłych, także do ich doczesnych szczątków, będących przedmiotem zainteresowania tak archeologów, jak i „hien cmentarnych”; 
(e) ład społeczny w tym poszanowanie własności publicznej i prywatnej oraz

(f) stosunek do zasad i praw ustalanych z myślą o zachowaniu dziedzictwa dla przyszłych pokoleń.

Za istotną w kontekście powyższych rozważań należy uznać m.in. potrzebę transdyscyplinarnej dyskusji nad tym, co i dlaczego jest traktowane jako „zabytek archeologiczny” oraz jak typ działań zapewnia ochronę materialnym pozostałościom po XX wiecznych wydarzeniach. Co ciekawe, zgodnie z art. 6 pkt. 3 ustawy z dnia 23 lipca 2003 r. jedna z form ochrony zabytków tj. wpis do rejestru zabytków z trudem (poza pochówkami z czasów wojny) odnosi się do tej kategorii: „Ochronie i opiece podlegają bowiem bez względu na stan zachowania, zabytki archeologiczne będące w szczególności: pozostałościami terenowymi pradziejowego i historycznego osadnictwa, cmentarzyska, kurhany, relikty działalności gospodarczej, religijnej i artystycznej” (za stroną Internetową NID). Pozostałości działań militarnych - na nasze nieszczęście towarzyszące człowiekowi od zarania po dzień wczorajszy - nie zostały w tym dokumencie wyszczególnione. Składa się na to wiele powodów wymagających wnikliwszej i pilnej analizy.

Postrzeganie archeologii jako zaczynu procesu pogłębiania wrażliwości i świadomości historycznej w odniesieniu do wschodniego krajobrazu pogazowego wymagałoby aktualnie nadludzkiego optymizmu. To co materialnie po-zostało po działaniach militarnych, jakie miały miejsce na terenie dzisiejszej Polski w trakcie I wojny światowej, pomimo, że boryka się z licznymi utrudnieniami wciąż trwa i nie jest osamotnione w swym trwaniu. Na trajektorie przekształcania (się) z przeszłego w teraźniejsze, wpływały i wciąż wpływają różnorodne czynniki i podmioty sprawcze.

Szczęśliwie, nie tylko ludzie są w stanie udzielać lekcji szacunku dla tego, co minione i zrozumienia dla tego, co aktualne. Udziela ich także materia nieożywiona, również ta, zaktywizowana do istnienia przed stu laty w kontekście użycia broni chemicznej. Dziś fragmentaryczna i zdeformowana. Wciąż jednak nie-nieobecna. 
